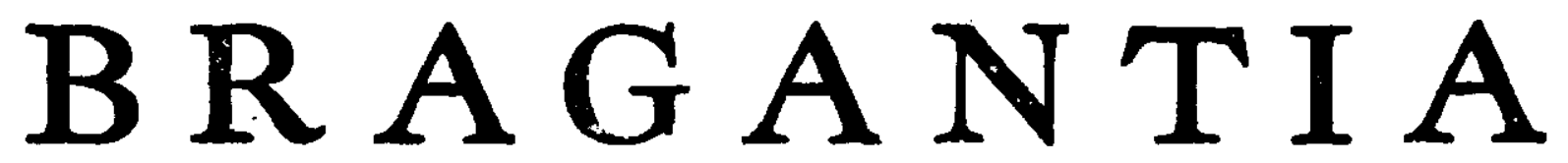

Boletim Técnico da Divisĩo de Experimenlação e Pesquisas IN S T I T U T O A G RONÔMICO

\begin{tabular}{lll}
\hline \hline Vol. 3 & Campinas, Setembro de 1943 & N. 9 \\
\hline \hline
\end{tabular}

\title{
ROCHAS-MATER DA "TERRA ROXA"
}

M. Gutmans

O extraordinário progresso da física e química nos últimos anos fêz evoluir tôdas as ciências naturais. Basta citar os novos métodos analíticos que revelam um miligramo do rádio dispersado em 10 toneladas da rocha para se apreciar as sensacionais descobertas na ciência.

Sabemos, por intermédio da mais rigorosa experimentação, que, em muitos casos, alguns $\mathrm{Kg}$ de substância química valem mais, como fertilizante, do que centenas de toneladas de estêrco, adubo consagrado pelos milênios da prática agrícola.

Paralelamente ao desenvolvimento da análise química, progrediram os outros métodos analíticos.

Nos últimos anos ficamos conhecendo a composição mineralógica de argilas de várias partes do mundo, tendo, de 1937 a 1940, a Secção de Solos do Instituto Agrônomico contribuido com seu quinhão, efetuando as análises pelos raios X de várias argilas do Estado de São Paulo (1). A argila, parte do solo que fornece o máximo dos elementos minerais às plantas, é produto de decomposição das rochas.

No caso de um solo autóctone, as relações entre o solo e a sua rochamater s̃̃o claras: o solo é constituido dos minerais da rocha-mater, em parte decompostos e em parte transformados pela ação dos agentes atmosféricos, e ainda misturados com restos de plantas.

Os solos autóctones predominam nos planaltos com formações geológicass horizontais ou pouco inclinadas. $\mathrm{Na}$ superfície, por muitos quilômetrcs quadrados, o solo é o produto de uma única rocha.

Classificando os solos do Estado de São Paulo do ponto de vista petrográfico, podemos agrupá-los em duas grandes categorias principais : solos simples, os formados por uma única rocha, e solos complexos.

O Estado de São Paulo ficará assim dividido em duas porções por uma linha curva que separa a formação permiano-glacial, das predevonianas.

A parte do Estado, a noroeste dêste limite, é a zona dos solos simples da qual faz parie a formação devoniana; a outra menor, a sudeste, é a dos solos complexos.

Na primeira porção também encontramos, mas em evidente minoria, solos complexos nos vales, onde os rios misturam os detritos de diferentes formações.

A maior parte da zona de solos simples do Estado de São Paulo pode ser subdividida em 33 sub-regiões, as quais coincidem com as ocorrências 
das 33 rochas principais, que constituem 7 formações geológicas distintas, começando pela devoniana e terminando pela formação da época atual.

O mapa geológico de 1929, da Comissão Geográfica e Geológica, na escala 1:1.000.000, naturalmente não podia levar em consideração as diferentes rochas que compõem as formações geológicas, e, assim, solos muito diferentes se encontram em faixas indicadas por uma só côr.

O futuro mapa agro-geológico da formação glacial, no qual se encontram vários tilitos, separados pelos argilitos, arenitos e conglomerados, apresentará mais caleidoscópico aspecto. Do ponto de vista prátíco devem ser bem discriminadas estas rochas da época permiano-glacial porque, enquanto os tilitos originam muito bons solos, os arenitos dão os piores do Estado.

A mesma discriminação deve aplicar-se aos solos dos diabásios e dos arenitos de São Bento : o solo originado do diabásio é a famosa «terraroxa».

As inúmeras análises de várias terras roxas e vermelhas, feitas pela Secção de Solos do Instituto Agronômico, em Campinas, comprovaram a existência de vários tipos de terra-roxa.

Vageler considerou que a terra roxa legítima e autóctone não devia conter quarzo (areia) e, que, quando êste se encontrava presente, provinha do arenito de São Bento, podendo-se, assim, considerá-la como terra roxa mais ou menos misturada.

Hoje, pelas análises mineralógicas, vê-se que existem diabásios que contêm quarzo e outros que não o contêm. Sendo assim, a presença de quarzo em pequena quantidade pode existir mesmo na terra roxa legítima e autóctone.

No Estado de São Paulo existem, portanto, duas variedades importantes de diabásios: com quarzo e sem quarzo.

Mais adiante falaremos com maiores detalhes dessas variedades; por ora nos limitaremos a dizer que o quarzo encontrado nos diabásios tem o mesmo tamanho dos quarzos da "terra roxa falsa", achando-se uniformemente distribuido nos demais componentes dessas rochas, os quais, depois da decomposição, formam a parte argilosa da terra roxa.

Os diabásios e as terras roxas constituem um bom exemplo da necessidade de estudos mais minuciosos das rochas que os até aquí efetuados.

Apareceram, há poucos anos, dois excelentes estudos sôbre os dia básios, ambos sem nenhuma relação com a agricultura: um de Djalma Guimarães, "Província magmática do Brasil meridional» (5) e outro de $\mathrm{K}$. Walther, "Contribución al conocimiento de las rocas «basalticas» de la formación de Gondwana en la America del Sud (3).

Valemo-nos amplamente do primeiro (5), cuja parte cetrográfica foi, quase tôda ela, baseada no método Fedorow.

No segundo (3), porém, não há menção alguma do método Fedorow, e os componentes dos diabásios ficaram com determinações bastante 
vagas, mas as análises químicas dos diabásios brasileiros, argentinos, uruguaios e paraguaios, constituiram valioso material para nossos estudos comparativos sôbre as variedades do diabásio.

$\mathrm{Na}$ região predevoniana, não são evidentes as relações entre as rochas e as terras que as cobrem, como acontece nos planaltos.

Os solos autóctones são muito raros, mas o estudo assíduo da região, tendo-se à mão um mapa geológico detalhado, pode permitir a colheita de amostras do solo de tôdas as rochas predevonianas.

$\mathrm{Na}$ falta de planaltos com formações geológicas horizontais, é preciso colhêr as amostras do solo autóctone, nos altos dos morros graníticos, gneíssicos, calcáreos, etc.

Podemos, assim, assinalar 9 variedades dos mais importantes solos da região predevoniana, porque êste é o número das principais rochas aí existentes: areníticos, quarzíticos, filíticos, xistoso-micáceos, gneíssicos, anfibolíticos, calcáreos, dolomíticos e tipo terra roxa, oriundas do gabro.

Outros solos são mesclas, mas sua classificação, conservando-se sempre o mesmo critério geológico, é mais fácil do que parece.

A natureza, destruindo as inúmeras rochas da região, submete os produtos de desagregação a uma classificação natural, que simplifica oportunamente as pesquisas.

Múltiplas variedades de quarzos, feldspatos, piroxênios, anfibólios e micas ficam reduzidas a argilas, compostas sòmente de 11 minerais, segundo Paiva Netto (2).

Os quarzos, calcedônios, opalos, feldspatos, micas, ferro-óxidos, ilmenita, monazita, turmalina, almandina, apatita, piroxênios e anfibólios são os componentes principais da fração areia dos solos do Estado de São Paulo.

A classificação dos solos na base petrográfico-geológica permitirá distinguir tôdas as variedades dos solos do Estado, evitando a confusão das classificações práticas com vagas determinações.

O método primitivo de "analisar a terra com o pé» deve ceder lugar ao estudo científico, baseado em conhecimentos completos das rochas, das quais se originaram os solos agrícolas.

O presente estudo é dedicado às rochas basálticas, que originaram um dos melhores solos do Brasil : a "terra roxa".

\section{VARIEDADES DAS ROCHAS BASÁLTICAS DO ESTADO DE SÃO PAULO.}

Antes de descrever as variedades das rochas basálticas do Estado de São Paulo, trataremos ligeiramente do magma, donde elas se originaram.

Às nossas rochas basálticas estão ligadas estreitamente, em muitos pontos do Brasil e de outros países vizinhos (Paraguai e Argentina), as 
rochas sódicas (Itatiaia, Distrito Federal, Poços de Caldas, Jacupiranga, etc.).

Guimarães (5) considera estas rochas sódicas como um produto de diferenciação de um magma basáltico.

Walther (3) acha que esta questão ainda não foi resolvida (p. 157 do trabalho citado), principalmente porque ainda não se concluiram as investigações nas regiões de Poços de Caldas e de Lages.

Se admitirmos a diferenciação de nossas rochas basálticas e sódicas a partir de um magma de idêntica origem genética (tão importante na moderna classificação), essa diferenciação será muito diferente daquela que seria aceita, caso fôssem dois magmas.

Antes de compararmos as composições mineralógicas das rochas em questão, passemos em revista as análises químicas.

Nas 12 rochas sódicas brasileiras (4)

\begin{tabular}{|c|c|c|c|}
\hline $\begin{array}{c}\text { o teor de } \\
\text { " } \\
" 1 \\
" 1\end{array}$ & $\begin{array}{l}\mathrm{Al}^{2} \mathrm{O}^{3} \\
\mathrm{CaO} \\
\mathrm{Na}^{2} \mathrm{O} \\
\mathrm{K}=\mathrm{O}\end{array}$ & $\begin{array}{c}\text { oscila entre } \\
\text { " } \\
\text { ", }\end{array}$ & $\begin{array}{r}19,32- \\
0,32- \\
5,65- \\
3,96-\end{array}$ \\
\hline
\end{tabular}

Nas 20 rochas basálticas (3)

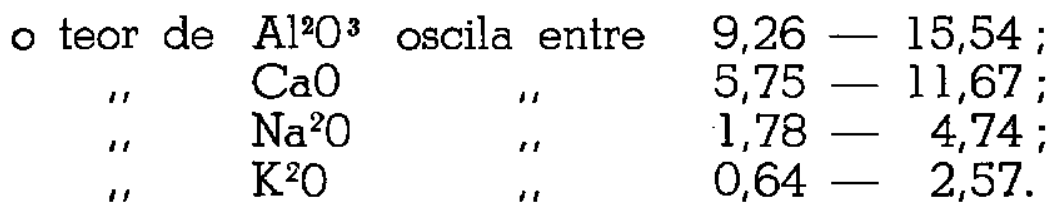

É evidente a notável dịferença entre as rochas basálticas e sódicas.

$\mathrm{Na}$ região de Poços de Caldas foram analisadas tôdas as rochas sódicas, começando pelos foiátos de grão grosso e terminando pelos fonolitos afaníticos. Tôdas as variações encontradas apresentam as composições químicas típicas das rochas sódicas; não se encontrando rocha alguma com a composição intermédia das rochas basálticas.

Entre a região de Poços de Caldas, com as suas rochas sódicas, e a região limítrofe de Prata, onde começam a aparecer as rochas basálticas, existe a região intermediária de Cascata, onde abundam as brechas vulcânicas, ainda não analisadas quìmicamente. Estas rochas devem dar a composição química intermediária, mas é evidente tratar-se de breccia - onde houve mescla mecânica das rochas de dois magmas diferentes.

Veremos mais adiante que em outras regiões do Estado de São Paulo existem as rochas intermediárias entre as rochas sódicas e basálticas.

As rochas basálticas estudadas por Walther (3) foram obtidas em diferentes localidades do. Brasil, Argentina, Uruguai e Paraguai. 
Não obstante a diversidade dos locais em que foram tomadas, as amostras não apresentam tôdas as variedades das rochas basálticas.

Faltam as variedades gabróides, que correspondem aos foiaítos do magma sódico.

Citaremos, a seguir, um trecho do tratado de Walther (3) (pág. 4) : ......El mapa geológico del Brasil publicado por Branner, no satisface en lo tocante a la extension de las rocas, pues las "diabases" que atraviesan el fundamento cristalino, y de las que también Baker señala algunas, con toda seguridad y en la gran mayoria de los casos, no tienen ninguma relación con las rocas gondwánicas, a pesar de su parecido petrográfico; en parte, no forman sino el séquito lamprofídico de antiguas rocas intrusivas. Corresponden aquí también los filones de "meláfido" de los alrededores de Montevideo, descritos por mí e mencionados por Baker»......

Onde ficam então as frações gabróides correspondentes ao magma basáltico?

Será possível que todos os gabros permaneçam ainda sepultados debaixo dos mantos espêssos das rochas basálticas efusivas?

Uma tal suposição seria ousada, em vista do trabalho contínuo da erosão, que, em muitos pontos, eliminou completamente os mantos e as séries compostas de vários mantos espêssos.

Nota-se principalmente a erosão enérgica, nas zonas litorâneas, cujo embasamento é cristalino.

É verdade que os mantos e os filões diabásicos se concentram nas regióes postalgonquianas, mas as observações diretas demonstram a presença dos mesmos diabásios na zona cristalina.

Desde início, as pesquisas das terras roxas e das suas rochas-mater foram dirigidas pelo Instituto Agronômico para tôda a área do Estado de São Paulo, sem excluir a faixa litorânea de embasamento cristalino.

As numerosas amostras de diabásios colhidas entre os gneisses (fig. 10) e os xistos antigos deram as mesmas análises mineralbgicas que os diabásios do interior do Estado.

Como um bom exemplo citaremos os diabásios da região de Monte Alegre, a $15 \mathrm{Km}$ de Amparo.

Entre os gneisses biotítico-anfibolíticos, a $5 \mathrm{Km}$ ao norte da Vila Monte Alegre, aparece um diabásio de grão fino, cortando os gneisses oblìquamente ao rumo geral da formação cristalina.

O microscópio demonstra tratar-se do diabásio da mesma composição dos que freqùentemente afloram na formação permiana glacial entre Amparo e Serra Negra.

Os plagioclásios têm a composição $A_{n_{50}}-A n_{56}$.

Os piroxênios são diopsídios magnesianos.

O minério é uma magnetita ilmenítica. 
O diabásio não demonstra indício algum do acentuado metamorfismo que possuem tôdas as outras rochas da região predevoniana de Monte Alegre.

Evidentemente, o diabásio é muito mais recente do que os gneisses, anfibolitos, os quarzitos e outros xistos predevonianos.

É evidente também que a região predevoniana em geral, como embasamento para tôdas as formações posteriores, foi cortada repetidas vêzes por erupções básicas.

Os casos de diabásios mais antigos, fortemente anfibolitizados, são várias vêzes citados na literatura brasileira.

Não podemos aquí repetir a descrição dos diabásios metamorfos, pois o importante para as nossas considerações é o gabro, que pertence à mesma família de nossos diabásios e é relativamente abundante na zona de xistos cristalinos no Estado de São Paulo e Paraná, e, provàvelmente, em outros Estados litorâneos.

Um exemplo, é o gabro de São Bento de Sapucaí (fig. 3).

Êsse gabro aflora em vários pontos, a distâncias de alguns quilômetros, nas orlas do rio Sapucaí-Mirim e seus afluentes.

A estrutura da rocha é gabróida.

A preponderância do anortósio e do ortósio sódico nestes gabros exclue-os da família dos gabros normais, motivando uma denominação nova - bocaiuvitos (vide mais adiante).

Quase todos os plagioclásios são geminados segundo o eixo (001) com o plano de junção (010). A composição de plagioclásios é $A n_{43}-\mathrm{An}_{50}$.

Em volume total muito menor aparece o anortósio, sem formas nítidas, com $2 \mathrm{~V}=-54^{\circ}-59^{\circ}$.

O piroxênio, com modalidades de côres fracas, amarelentas e, avermelhado-marrons do pleocroismo, demonstra as hemitropias caraterísticas com $\mathrm{Nm}$ em comum, e $\mathrm{Ng}$, de uma metade, coincidindo com $\mathrm{Np}$ de outra metade, necessitando Ng: $\mathrm{c}=45^{\circ} ; 2 \mathrm{~V}=+42^{\circ}$.

A dispersão do eixo b́tico, próximo ao (001), é nitidamente $p>v$.

A dispersão do outro eixo ótico é muito fraca, sendo quase impossivel determinar o caráter da dispersão.

O piroxênio é o diopsídio magnesiano, como os piroxênios de tôdas as eruptivas básicas triássicas do Brasil Meridional.

A magnetita ilmenítica em grãos informes circundados pela mica castanha fortemente pleocróica, está incluida ou ligada com os cristais do diopsídio magnesiano e, pelo seu volume total, ocupa o terceiro lugar, depois dos feldspatos e diopsídios.

Em quarto lugar vem a olivina, contendo serpentina amarela nas fendas.

Entre os minerais acessórios aparecem a apatita, em prismas hexagonais bem formados, e a biotita marrom, fortemente pleocróica. 
Gabro da mesma composição encontra-se nas proximidades de Jacupiranga.

A diferença entre êste e o anterior consiste na maior quantidade de piroxênio, que iguala o volume total dos feldspatos, e na abundância de magnetita e ilmenita. A olivina, com $2 \mathrm{~V}=-78^{\circ}$, que corresponde à hialosiderita, fica em quinto lugar e o grau de serpentinização é o mesmo.

Entre os feldspatos, o anortósio é de maior importância pelo volume que ocupa.

Os plagioclásios, em cristais alongados. muito menores, ocupam o quarto lugar, com relação ao volume. A apatita encontra-se presente.

É notável a constância dos minerais com tôdas as mudanças em suas proporções e dimensões, não obstante a distância de $320 \mathrm{Km}$ em linha reta entre as duas ocorrências.

É evidente que as proporções entre os minerais-componentes são resultado das leis físico-químicas de cristalização fracionada, complicada pelos fenômenos mecânicos do movimento do magma em cristalização.

Podemos descer mais $120 \mathrm{Km}$ ao sul, seguindo o litoral, e encontraremos perto de Curitiba (na estrada federal Curitiba - São Paulo) vários afloramentos do mesmo gabro. mudam.

Os minerais componentes ficam os mesmos, mas a proporções

A $12,4 \mathrm{Km}$ de Ribeira, com rumo a Curitiba, aflora o gabro que revela um bonito e interessante quadro na lâmina sob o microscópio: em grandes cristais de anortósio estão irregularmente distribuidas as ripas do plagioclásio, fornecendo um belo exemplo da estrutura poiquilítica (fig. 4 e 7).

Pelo volume ocupado em volume total da rocha, os minerais-componentes seguem a ordem: anortósio, diopsídio magnesiano, plagioclásios, minério, olivina, biotita, apatita.

Não penetramos ao sul de Curitiba, mas temos a certeza de que o nosso gabro, com poucas variações em sua composição, também se encontra no Estado de Santa Catarina, Rio-Grande-do-Sul e Uruguai.

A tendência sódica, manifestada pela presença de anortósios ou ortósios sódicos, no caso do gabro de São Bento de Sapucaí, explica-se pela proximidade do maciço de Itatiaia.

A distância entre êste ponto e o Pico de Itatiaia é de $220 \mathrm{Km}$ em linha reta.

A distância entre o gabro, descrito em último lugar, e o de Jacupiranga, é de $170 \mathrm{Km}$.

Em ambos os casos é importante que essas distâncias sejam medidas pelo rumo das principais linhas tectônicas, coincidindo alí com os rumos das extensões máximas das diferentes rochas que entram na composição da formação predevoniana. 
São abundantes as rochas básicas nesta formação, mas os gabros descritos distinguem-se pela sua boa conservação e constância de seus componentes.

Sòmente as rochas basálticas do Brasil Meridional demonstram as mesmas qualidades em distâncias ainda maiores (fig. 8 e 9).

Assim, sem base química alguma, mas orientando-nos por determinações óticas dos minerais-componentes, principalmente os feldspatos e augitos, colocamos os gabros descritos na mesma família dos eruptivos básicos, descritos mais adiante.

Os gabros fornecem as rochas intermediárias entre as rochas basálticas e as rochas sódicas, ficando assim comprovada a relação atlântica dos eruptivos básicos triássicos do Brasil Meridional.

Hussak (5) distingue 2 classes principais nas rochas basálticas do Brasil Meridional : os diabásios normais e os augito-porfiritos.

Walther (3) usa a denominação "dolerita" para as rochas basálticas de estrutura ofítica, diabásico-granosa ou intersertal e "porfiritas plagioclássicas e augíticas" para tôdas as outras rochas basálticas efusivas da mesma idade.

Walther (3) (pág. 18) propõe ainda dividir as doleríticas em 3 grupos:

1. Mais ricas em mesostasis;

2. Tipo dolerítico mais pronunciado;

3. Doleritas afaníticas de grão fino;

As porfiritas, Walther (3) também as divide em 3 grupos:

1. Porfiritas - doleritas ;

2. ${ }^{\circ}$ Porfiritas com fenocristais grandes, visíveis a ôlho nu;

3. ${ }^{\circ}$ Vitrofiritos.

O próprio Walter (3) chama sua classificação de provisória.

Citamo-la, entretanto, para assinalar as dificuldades com que luta ainda a petrografia para conseguir uma boa classificação das rochas basálticas.

Entretanto, a exata classificação é perfeitamente possível baseando-se em determinações mais precisas dos minerais-componentes, o que é agora possível pelo uso do método Fedorow, para os feldspatos e os piroxênios.

Walther (3) menciona os seguintes plagioclásios:

No $1 .{ }^{\circ}$ grupo das doleritas: labradoritas, às vêzes andesínicas, às vêzes bitowníticas ;

no $26^{\circ}$ grupo das doleritas predomina o labrador, mas encontram-se tôdas as variedades, desde o oligoclásio até quase a bitownita-anortita ;

no $3 .^{\circ}$ grupo a albita básica une-se às variedades citadas. 
No $1 .^{\circ}$ grupo das porfiritas observaram-se o labrador e o labrador bitownítico ;

no $2 .^{\circ}$ grupo observaram-se os mesmos plagioclásios, porém algumas vêzes observaram-se bitownitas-anortitas ;

- $3 .^{\circ}$ grupo apresenta tôdas as variedades, desde o labrador bitownítico até o oligoclásio.

Dêste pequeno resumo poder-se-ia chegar à conclusão de que a determinação exata dos feldspatos das rochas basálticas pelo método Fedorow seria inútil para distinguir as variedades das rochas basálticas, porque as duas classes principais de rochas basálticas contêm os mesmos feldspatos.

O petrógrafo, com todo o seu instrumentário complicado moderno, para distinguir os diabásios e as porfiritas e as sub-categorias dos mesmos, deveria limitar-se ao estudo a vista desarmada?

Felizmente, para a nossa ciência, não é assim, como veremos mais adiante.

Deixamos de lado a discussão estéril sôbre a exatidão dos têrmos diabásio, dolerita, basalto, etc., porque, nem a investigação histórica dêstes têrmos, maravilhosamente efetuada por Johannsen (6), nem as considerações sôbre o seu uso na literatura especial dessa terminologia podem resolver definitivamente o assunto.

A idéia dêsse trabalho era encontrar o método para distinguir nitidamente as variedades mais comuns das rochas basálticas e caraterizá-las para fins agro-geológicos.

Para conseguir nosso profósito seria suficiente indicar as variações dos componentes-minerais das rochas basálticas, indicando as outras propriedades, mais comuns e acessíveis das mesmas, em conexão com a sua composição mineral, absolutamente indispensável para a classificação.

Para cada rocha estudada empregaremos o têrmo mais conhecido, usado na literatura petrográfica moderna para as rochas basálticas, sem atribuir a qualquer dêstes têrmos a exatidão da terminologia científica ideal.

Os nossos tipos serão bem definidos, não pela terminologia, mas, sim, pela análise microscópica dos componentes.

Devemos observar que seria deixar o assunto insuficientemente esclarecido se o estudo microscópico fôsse considerado apto para definir todos os tipos de rochas basálticas.

Mais adiante, veremos que, para muitas rochas basálticas afaníticas, o único método da determinação dos minerais componentes é o de Fedorow, ou êste combinado com algum outro.

Quem não dispõe de instrumentos óticos para o estudo microscópico dás rochas, é forçado a recorrer à observação da côr, do tamanho dos grãos viś́veis, do modo da ocorrência, da idade geológica, etc. 
Estes métodos, sem a arma analítica moderna, permitem que nos orientemos quanto às rochas de grão grosso, como, por exemplo, granitos, gneisses, etc., mas são inadequados para as rochas basálticas.

No campo, não desprezamos, porém, as observações macroscópicas.

Mais adiante, forneceremos tôdas estas observações, que podem facilitar grandemente a tarefa no campo, quando não há possibilidade de fazer as lâminas das rochas e estudá-las microscòpicamente.

Queremos ressaltar que só essas observações macroscópicas são inúteis para distinguir as variedades de rochas basálticas, dispersas numa superfície de $1.000 .000 \mathrm{Km}^{2}$, aproximadamente.

\section{MELÁFIROS}

Desde início devemos notar que usaremos a denominação «meláfiros» sem pretender definir com uma só palavra as rochas basálticas aquí descritas.

No decurso dêste trabalho nossas rochas serão bem definidas pelos seus componentes minerais e daremos atenção especial e definição precisa aos principais componentes.

A literatura petrográfica e geológica sôbre os meláfiros não dá definição exata.

A. Brogniart (6) usou primeiramente o têrmo "melaphyre» para os andesitos e basaltos e Rosenbusch (6) definiu os meláfiros como basaltos paleozóicos.

Johannsen (6) aconselha abandonar o têrmo; o abandono dêste nos obrigaria a inventar um novo, para a nossa primeira classe de rochas basálticas.

Preferimos adotar a definição de Guimarães (5) : «Os meláfiros são os basaltitos amigdalóides em que a massa fundamental não sofreu alteração».

Incluímos entre os meláfiros também os espilitos, ou os basaltitos vesiculares alterados, que Guimarães (5) considera como os «meláfiros albitizados».

Para apresentar as análises mineralogicas de meláfiros, foram colhidas centenas de amostras em vários pontos do Estado de São Paulo e dos Estados vizinhos. Dezenas de lâminas foram preparadas e examinadas microscòpicamente. A maior parte das lâminas não forneceu feldspato algum para a determinação exata das geminações.

Os meláfiros estão sujeitos à decomposição rápida pelos agentes atmosféricos, graças à sua porosidade.

Os meláfiros pertencem às rochas efusivas porque assim devemos considerar as rochas ígneas que ficaram a pequena profundidade, isto é, a algumas dezenas de metros, e chegaram à superfície só por causa da erosão muito tempo após as mesmas se haverem consolidado.

A região de Franca apresenta vários meláfiros, que se introduziram nas camadas superiores do arenito Botucatú. 
Alí, os meláfiros aparecem em quase tôdas as gargantas denominadas «furnas», formadas pela erosão no arenito Botucatú, cuja profundidade atinge até $100-150 \mathrm{~m}$.

A estrutura dos meláfiros nas partes inferiores é idêntica à da lava basáltica, quando entra em contacto com a superfície das rochas sedimentares. $\bar{A}$ identidade das estruturas explica-se naturalmente pelas iguais condições de consolidação.

A pressão e a temperatura eram as mesmas no fundo da espêssa camada de intrusão melafírica, pois estas alcançam muitas vêzes 100 a 200 metros.

A nossa amostra de meláfiro das Furnas de São Pedro foi colhida na parte baixa da camada intrusiva melafírica, por serem inacessíveis as outras partes da camada.

Em geral, as partes inferiores da camada melafírica são mais fortemente decompostas que as partes superiores ou médias, porque as águas freáticas se concentram nas partes porosas inferiores dos meláfiros.

Debaixo do meláfiro, o arenito, endurecido pelo contacto, apresenta um sério obstáculo para a penetração das águas freáticas. Assim se explica que os meláfiros afloram em tôdas as gargantas lavadas pelas fontes que surgem no limite entre os meláfiros e os arenitos.

Afloram os meláfiros nas proximidades de Ribeirão Preto à distância de 7 quilômetros a oeste da cidade.

Na Estação Experimental de Ribeirão Preto os meláfiros apareceram à profundidade de 30 metros.

Nas cotas mais baixas do terreno da Estação Experimental, afloram os meláfiros.

O resultado das análises de meláfiros obtidos em vários pontos do Estado, bem distantes entre si, é surpreendente.

Nossas pesquisas demonstram que os meláfiros, embora procedentes do mesmo magma, como as outras rochas basálticas, têm a composição química e mineralógica bem diferente, sem falar da sua estrutura.

Não se trata de alguma exceção, para confirmar a regra geral. Trata-se de erupções em extensão enorme, abarcando, fora do Brasil Meridional, o território de Missiones, na Argentina, Paraguai e Uruguai.

É muito provável que as rochas diabásicas de Roroima pertençam ao nosso sistema eruptivo.

As condições das erupções basálticas da África do Sul demonstram as mesmas relações entre as rochas melafíricas e as outras.

As nossas pesquisas demonstram (vide mais adiante) que o magma basáltico, antes de chegar nas proximidades da superfície, devia vencer em forma de fendas estreitas, verticais, os vários obstáculos e os contactos horizontais com as camadas de sedimentos.

O caminhamento através dos obstáculos devia estender-se à distância de várias dezenas de quilômetros. 
Não se tratava de um líquido uniforme, com temperatura muito acima de seu ponto de fusão.

O magma basáltico no início mesmo de seu movimento já estava carregado de cristais e a restante massa líquida tinha a temperatura apenas de alguns graus centígrados acima do seu ponto de cristalização.

Neste estado, o magma possuía pouco poder absorvente.

As rochas sedimentares, por onde o magma passou, são pouco metamorfizadas.

Na maioria dos casos, todo o metamorfismo se limitou ao endurecimento e à silicificação do cimento argiloso-ferruginoso, entre os grãos do quarzo.

Filtrado pelas fendas de tôdas as formações, desde a arqueana até a do arenito de São Bento, o magma basáltico deixou, na profundidade, todos os cristais já formados, na maior parte, os piroxênios e os plagioclásios básicos, como o labrador e a bitownita, e consolidou-se, como rocha mais ácida, com os feldspatos de composição $A n_{20}-A n_{3 ;}$ (vide mais abaixo as descrições das ocorrências dos meláfiros).

Os meláfiros são então da família andesítica, segundo a sua composição mineralógica e, de família basáltica, segundo a origem genética do magma.

$\mathrm{Na}$ realidade, o magma não é, como já observámos, de tendência andesítica, dada a composição da fase gabróide.

Como explicámos acima, tôdas as amostras efusivas ou intrusivas de pouca profundidade já não têm a composição do magma primário, mas a sua composição é mais ácida.

Os meláfiros, em sua massa principal, eliminando os abundantes minerais secundários, depositados nos poros, são, em geral, de côr preta, mas, onde o magma basáltico alcançou a superfície, a côr preta se transformou ràpidamente em vermelho-escura.

Para a agricultura, os minerais secundários que abundam nos meláfiros, têm considerável importância, porque, em muitos casos, fornecem - cálcio, que entra em menor proporção na massa geral dos meláfiros que nas outras rochas basálticas em questão.

Guimarães (5) cita os seguintes minerais nos geodos, vesículas e amígdalas dos meláfiros: ágata, calcedônia, quarzo, calcita, heulandita, desmina, mesolita, scolezita, girolita, apofilita, laumontita, analcita, viridita, clorita, cobre, malaquita e siderose.

Damos, a seguir, algumas caraterísticas das amostras de meláfiros: Amostra 1. Manto melafírico de Pirajú, na margem direita do rio Paranapanema. A amostra foi tirada da parte média do manto, à entrada da usina hidro-elétrica. Alt. absoluta $550 \mathrm{~m}$. O meláfiro tem poros raros, que contêm, na maior parte, calcita. Os cristais de calcita alcançam às vêzes o comprimento de $20 \mathrm{~mm}$.

Os plagioclásios são muito péquenos e raramente são visíveis a ôlho nu. 
Feldspato N. ${ }^{\circ}$ 1, geminado segundo Albito-Esterel, com o plano de junção (010), deu $43 \%$ An, deduzido de $44 \%$ de geminação e $42 \%$ do plano de junção, segundo os diagramas Berek.

Feldspato N. ${ }^{\circ}$, geminado segundo a lei Albito-Karlsbad, deu $35 \%$ An pela geminação.

A média de conteúdo de An é de 39\% An. O feldspato predomina formando 7C\% aproximadamente dos fenocristais.

Em segundo lugar vem a augita, às vêzes com cristais bem formados, mas, na maior parte, transformados em agregados microlíticos de clorita.

A magnetita e a ilmenita em grãos informes e formas arborizadas, indicando o rápido resfriamento do magma, aparecem em duas gerações.

É interessante a abundância das vênulas cheias de grãos redondos de quarzo.

É impossível, neste caso, admitir a penetração da areia por gravidade; trata-se de minúsculas escamas do arenito de São Bento, arrastadas pelo manto melafírico, durante a erupção.

Amostra 2. Intrusão melafírica de Pedregulhos, de $70 \mathrm{~m}$ de espessura, em furnas de São Pedro, perto de Pedregulhos. Parte inferior, em contacto com o arenito de Botucatú.

Em tôda a espessura da intrusão podem ser observados os poros, mas nota-se a maior porosidade na parte inferior do "sill», perto do contacto.

Os vapores de água originados na parte superior do arenito úmido, subjacente, penetraram no magma já bastante viscoso, formando uma camada melafírica porosa de cêrca de 0,5 - 1,0 m de espessura.

Como no meláfiro de Pirajú, o magma formou a brecha vulcânica na parte inferior da intrusão.

Observam-se no magma fragmentos de arenito que podem atingir o diâmetro médio de 0,3-0,4 m sendo, entretanto, as vênulas mais abundantes, as quais são fàcilmente observadas ao microscópio.

Uma ação tão forte sôbre o arenito explica-se pelo estado muito viscoso do magma, desprovido de seus elementos mais básicos.

Trata-se de uma intrusão, porque acima do "sill» se observa ainda o arenito de Botucatú, ainda que em espessura que não supere alguns metros, porque, já na altitude de 950 m.s.n.m., se observam as camadas variegadas arenítico-argilosas da formação de Baurú, na entrada do norte para a cidade de Pedregulhos.

Por falta de tempo não podíamos estudar aquí mais detalhadamente a formação de Baurú. Observam-se bem nítidamente as rápidas variações da côr e do tamanho de grãos, que é uma cara- 
terística mais notável do arenito de Baurú em comparação com o arenito de Botucatú.

Como no meláfiro de Pirajú, predomina, entre os cristais maiores, o plagioclásio. O resto é formado pelos esqueletos arboriformes do minério com interstícios ocupados pelos grãos quase redondos de augita, na maior parte cloritizada.

Nos feldspatos observam-se principalmente as geminações segundo Albino-Esterel; com 25\% de anortita.

Os microsporos do meláfiro são ocupados pela clorita verde, não se observando a calcita nos mesmos.

Amostra 3. Camada intrusiva melafírica a $7 \mathrm{Km}$ a oeste de Ribeirão Preto. Espessura de alguns metros.

Num poço, 'escavado próximo ao estábulo da Estação Experimental de Ribeirão Preto, no lugar indicado acima, surgiu, na profundidade de $30 \mathrm{~m}$, uma camada melafírica fortemente decomposta.

Era impossível determinar os componentes mineralógicos dêste meláfiro.

A $2 \mathrm{Km}$ ao norte do poço, no mesmo nível da camada, aflora um meláfiro bastante fresco, que, provàvelmente, é a continuação do meláfiro do poço.

O conteúdo de anortita em feldspatos é de $38 \%$ (média de cinco determinações).

As geminações observadas são segundo Manebach-Periklin:

Nos poros foi depositada a heulandita com $2 \mathrm{~V}=35^{\circ}, 5$, diretamente observado pela platina de Fedorow, $\mathrm{Nm}=1,500$, com dispersão cruzada bem nítida.

A camada melafírica aflora entre as camadas diabásicas.

Não obstante a diferença notável do químismo, em forma dos andesinos nos meláfiros e dos labradoros nos diabásios, não se nota diferença grande na vegetação acima do meláfiro e do diabásio.

O lugar não é muito favorável para a comparação dos solos melafíricos e solos diabásicos, porque os solos formam um declive ainda que suave, mas que não impede o transporte e a erosão do solo.

É possível que a heulandita, que forma uma parte considerável do meláfiro (20 - 36\%, aprox.) e que não se encontra em diabásios, compense a falta relativa do cálcio nos meláfiros, em comparação com os diabásios. 


\section{DIABÁSIOS E PORFIRITOS-DIABÁSICOS.}

A história do têrmo "diabásio» é típica para tôdas as terminologais das rochas. Utilizamos, para apresentá-la, o excelente esbôço de Johannsen (6).

Certas rochas, compostas, segundo os minerálogos do século XVIII, de anfibólio, clorita e feldspato, foram chamadas, por Werner, "Gruensteine», "pedras verdes». Muito depois, no ano 1835, Gustav Rose demonstrou que "Gruensteine" são compostos de piroxênio, pouca clorita e labrador ou oligoclásio. A. Brongniart introduziu a denominação "diabásios» para os "Gruensteine" no ano de 1807, a-fim-de evitar a vaga expressão de "pedra verde", que utiliza a côr como seu caraterístico principal. Assim, desde início, devido à determinação errada da composição mineralógica, criou-se uma causa originadora de outras denominações errôneas.

Como diabásios foram classificadas as rochas verdes ou esverdeadas, compostas de anfibólio, clorita e feldspato, de um lado, e, de outro, as rochas da mesma côr compostas de piroxênio, clorita e feldspato.

Em 1827 (6) Brongniart escreveu que considera «utile a la science de diminuer autant que possible les synonymes qui fatiguent la mémoire et jettent de l'incertitude dans les déterminations».

Johannsen (6), que cita esta frase, é de opinião que o têrmo original "diabásio» fique eliminado.

Infelizmente, tal não se deu.

Uma vez introduzido um novo têrmo pela autoridade, a sua remoção pela mesma autoridade pouco importa, como demonstrou a história.

Zirkel (6), em 1866, generalizou o uso da palavra, aplicando o nome diabásio para tôdas as rochas, compostas de piroxênio e labrador, de grãos de todo tamanho.

Evidentemente, a ciência petrográfica descobriu ràpidamente novas variedades de rochas e existia uma premente necessidade de novos têrmos.

Qualquer têrmo antigo foi apressadamente retirado dos arquivos e lançado no campo confuso das terminologias.

A mesma vitalidade, do têrmo "diabásio», demonstrou o têrmo «dolerita», criado pelo abade Hauy (6) e determinando o basalto com granulação visível.

Walther (3) usou o têrmo «dolerita p porque queria evitar o uso do têrmo "diabásio».

Usaremos o têrmo "diabásio» com a especificação de Guimarães (5) : «Os diabásios são rochas intermediárias a basaltitos e gabros. A textura é intersticial e a granulação média. $O$ plagioclásio é idiomorfo, tabular; a augita é hipidiomorfa e, em alguns casos, idiomorfa. A mesostasis apresenta-se sempre, em maior ou menor proporção, em áreas irregulares limitadas pelos cristais alongados de plagioclásio ou diopsídio». 
Os diabásios afloram em todo o Brasil, começando pela Serra do Mar e terminando pela parte ocidental do Estado de Mato Grosso e extremo norte do Brasil.

A idade dos diabásios de Roroíma não está ainda bem estabelecida.

Glycon de Paiva (7) reputa cambriana a idade dos arenitos intrudidos pelos diabásios, deduzindo-se a idade postcambriana para o diabásio.

Iniciemos a nossa descrição pelo diabásio de Laranjal, onde a grande pedreira da Sorocabana permitiu penetrar profundamente no corpo do dique.

Colhemos as amostras num plano horizontal, que é o fundo da pedreira, na alt. de 500 m. s.n.m., aproximadamente.

$O$ dique tem, nesse plano, a espessura de $120-150 \mathrm{~m}$. Êle se inclina para o Norte - $70^{\circ}$ - Oeste, aproximadamente, e tem o rumo para $\circ$ Norte - 20. - Este, aproximadamente; à primeira vista aparenta tratar-se de um lacolito, porque as escavações penetraram, com uma frente semi-circular, a dentro do dique.

Mas os blocos soltos, de $1-2 \mathrm{~m}$ de diâmetro do diabásio, na superfície da terra, indicam nìtidamente a continuação do diabásio pelo rumo acima indicado.

Os fenômenos do contacto são bem visíveis.

No lado noroeste do dique os argilitos permianos são completamente descoloridos.

A próxima camada diabásica transformou-se em argila azulada, conservando ainda pedaços irregulares isolados da rocha viva, intacta. Pròximamente a êste diabásio metamorfizado aflora uma camada relativamente fina, de $0,3-0,4 \mathrm{~m}$, de brecha vulcânica, composta de diabásios de granulação muito variada.

Após a brecha, com rumo à parte central do dique, não se observam variações bruscas nas estruturas.

Observa-se a transição imperceptível da granulação fina à granulação grossa no centro do dique. A-de-mais, na parte central observam-se poros abundantes, na maior parte vazios, visíveis a ôlho desarmado.

Esses detalhes são importantes para compreender o processo da cristalização do magma diabásico. Voltaremos a êsse assunto mais adiante.

\section{Lâmina n. ${ }^{\circ} 161$.}

Amostra colhida na parte central do dique de Laranjal.

A rocha é bastante porosa, de grão grande e de côr cinzenta, observada de longe, visto ser mesclada de minerais pretos e outros quase brancos.

Ao microscópio observa-se a estrutura porfirítica. Os plagioclásios, que chegam a ocupar $70-75 \%$ do volume total, são idiomorfos. Os piroxênios demonstram raramente as facetas, formando muitas vêzes agrupamentos poiquilíticos no interior de 
grandes plagioclásios. Os piroxênios acham-se em decomposição evidente.

Os plagioclásios têm a composição mineralógica que oscila entre $\mathrm{An}_{20}$ - $\mathrm{An}_{51}$. Essas variações se observam geralmente em um fenocristal sem formar zonas distintas. A extinção não ocorre pelas zonas bem delimitadas, mas progride paulatinamente, como a extinção ondulada, porém difere desta pela sua orientação, definida: a parte mais básica se encontra sempre nas partes centrais dos plagioclásios. Nas bordas, os plagioclásios passam às zonas micropegmatíticas que se delimitam nitidamente.

O componente da micropegmatita é um ortósio sódico, com $2 \mathrm{~V}=$ - 53. Entre as micropegmatitas observam-se os grãos de quarzo.

A magnetita-ilmenita é estreitamente ligada a augita.

Piroxênio com fraco pleocroismo, $2 \mathrm{~V}=+44^{\circ}, \mathrm{ng}: \mathbf{c}=45^{\circ}$ e ângulo entre próximo eixo ótico $e * c »=23^{\circ}$.

\section{Lâmina n. 165.}

Amostra tomada, como a anterior, da parte central do dique, à distância de $25 \mathrm{~m}$ ao norte da amostra anterior, no mesmo nível de 500 m. s.n.m.

O aspecto a ôlho desarmado é quase o mesmo que o da rocha anterior. $\vec{A}$ distância de alguns metros, quando não se podem mais distinguir os componentes, a rocha apresenta-se cinzentada escura, em virtude de os minerais melanocráticos predominarem entre os minerais leucocráticos.

Na lâmina observam-se os plagioclásios idiomorfos, que não predominam tanto, como na amostra anterior, alcançando $50 \%$ do volume total aproximadamente.

Conserva-se a composição variável dos plagioclásios, que se manifesta pela extinção variável, mas contínua, em contraste com a extinção descontínua dos feldspatos nitidamente zonados.

Aliás, observa-se uma zona exterior, quando o plagioclásio está incluido num manto do ortósio sódico, que, por sua vez, é bem delimitada contra a massa micropegmatítica.

Como na amostra anterior, muitas vêzes o plagioclásio fica envolto em um manto de óxidos de ferro, e uma transição para a micropegmatita desaparece.

A composição dos plagioclásios oscila entre $\mathrm{An}_{38}-\mathrm{An}_{50}$. Observam-se as geminações segundo Albita, Karlsbad e AlbitaEsterel.

O piroxênio, com boa clivagem segundo (110) forma muitas vêzes maclas segundo (100). $\mathrm{Ng}-\mathrm{Np}=0,0235, \mathrm{Nm}-\mathrm{Np}=$ $0,0045, \mathrm{n}_{\mathrm{m}}=1,717 ; \mathrm{Z} \wedge \mathrm{c}=40^{\circ}, 5 ; 2 \mathrm{~V}=48^{\circ}$.

O pleocroísmo é muito fraco e indeterminável em seus com. ponentes. $\bar{A}$ apatita é abundante na mesostasis. $\bar{A}$ análise química 
comprovou a existência de $50,5 \%$ de $\mathrm{SiO}^{2}$. A estrutura é porfirítica, com plagioclásios e pirogênios idiomorfos, como na amostra anterior.

Os dados químicos são:

$\begin{array}{ll}\mathrm{SiO}^{2} & 50,5 \% \\ \mathrm{R}^{2} \mathrm{O}^{3} & 29,7 \% \\ \mathrm{CaO} & 7,3 \% \\ \mathrm{MgO} & 2,84 \% \\ \mathrm{Me}, \text { etc. })\end{array}$

Lâmina n.* 169.

Amostra colhida na parte intermediária do dique, entre o contacto no norte e a parte central do dique.

Aquí a rocha tem o grão mais fino e a côr mais escura do que na parte central do dique.

A composição dos plagioclásios é $A_{56}$.

As maclas observadas são geminadas segundo Karlsbad e Albita.

A estrutura é ofítica, com os plagioclásios idiomorfos e os augitos nos interstícios entre os feldspatos.

A mesostasis cloritizada ocupa $20 \%$ aproximadamente do volume da rocha.

A augita tem a extinção que aparece em manchas de contornos irregulares.

A clivagem carateriza-se por fendas sem a paralelidade nítida, que é necessária para a determinação exata dos ângulos entre $c$ e $\mathrm{Z}$ e de clivagem.

\section{Lâmina n. ${ }^{\circ} 164$.}

Amostra tomada da brecha na parte norte do dique, da zona do contacto. A amostra é de côr preta e de grão fino.

A estrutura microscópica é bem diferente das amostras anteriores que demonstravam a estrutura porfirítica (lâm. 161 e 165) e a estrutura ofítica (lâm. 169). Os plagioclásios são de todos os tamanhos, desde os micrólitos até os fenocristais, com tôdas as graduações igualmente representadas entre os tamanhos extremos.

As variações de tamanho surgem também entre os piroxênios, prevalecendo os fenocristais, que, em maior parte, são aglomerações de 4 - 10 grãos e dos micrólitos em forma dos grãos redondos.

A composição dos feldspatos varia entre $A n_{59}-A n_{72}$.

As geminações que aparecem são: periclínio, albita, Baveno direito, Manebach-Esterel e Albita-Karlsbad.

Nos piroxênios grandes observou-se: 


$$
\begin{gathered}
\mathrm{Z} \wedge \mathrm{c}=41^{\circ}-46^{\circ} .2 \mathrm{~V}=+42^{\circ}-50^{\circ} \\
\mathrm{Ng}-\mathrm{Np}=0,0226 \\
\mathrm{Ng}-\mathrm{Nm}=0,0196 \\
\mathrm{Nm}-\mathrm{Np}=0,0035
\end{gathered}
$$

\begin{tabular}{|c|c|}
\hline $\mathrm{SiO}^{2}$ & $48,9 \% \mathrm{x}$ \\
\hline $\mathrm{R}^{2} \mathrm{O}^{3}(\mathrm{Al}, \mathrm{Fe}$, etc. $)$ & $32,00 \%$ \\
\hline $\begin{array}{l}\mathrm{CaO} \\
\mathrm{MgO}\end{array}$ & $\begin{array}{l}9,7 \% \\
5,4 \% .\end{array}$ \\
\hline
\end{tabular}

Para comparação da composição química foram determinados os seguintes elementos da rocha:

A composição química dos grandes plagioclásios e dos plagioclásios microlíticos é idêntica.

Não há, tampouco, diferença notável entre os plagioclásios pequenos, completamente incluidos nos augitos, e os plagioclásios grandes, comparativamente menos isolados.

x) A rocha contém vênulas finíssimas de quarzo, em ramificações, aparecendo algumas delas apenas no limitado espaço de alguns milímetros quadrados.

$$
x^{x} x
$$

O estudo das rochas do dique de Laranjal conduz a algumas deduções importantes sôbre a gênese e a classificação das rochas basálticas.

A rocha da lâmina 164 não era a primeira, a começar a erupção, porque formou uma brecha com uma rocha eruptiva anterior que se consolidou.

O limite nítido entre a rocha de estrutura brechosa e a rocha intermediária (lâm. 169) indica que depois ocorreu uma nova intrusão e efusão.

Ao contrário, entre a rocha intermediária e a rocha central não podia observar-se delimitação nítida alguma.

Devemos admitir que o magma da rocha central seguiu o da rocha intermediária sem interrupção alguma do processo eruptivo.

magma intermediário estava ainda em estado semilíquido, não podendo formar uma brecha com o central.

As maiores diferenças de estrutura e da composição das rochas basálticas, que se observam no sul do Brasil e nas vizinhanças, explicam. se pelas diferenciações magmáticas em grande profundidade.

A erosão enérgica tropical eliminou, na Serra do Mar, milhares de metros de espessura das rochas superiores de cobertura, mas não descobriu ainda os focos principais da diferenciação das rochas basálticas. 
Nos últimos anos efetuaram-se vários trabalhos dispendiosos para elucidar a diferenciação das rochas basálticas.

Podemos citar, como exemplo, a pesquisa interessante de Wagner (8).

Em formações silurianas e devonianas aparecem na Turíngia Oriental 8 camadas diabásicas intrusivas, com espessuras que variam entre 40 e 250 metros.

Wagner (8) classifica as variações diabásicas em quarzodioritos, gabrodioritos e piroxenitos.

Baseando-se na ausência de discontinuidades visíveis a ôlho nu, êle considera que tôdas estas rochas são produtos de diferenciação magmática «in situ» do magma diabásico.

Já observamos no exemplo de Laranjal que as diferentes fases de erupção podem seguir uma a outra, antes da solidificação da fase precedente.

A-de-mais, na descrição da intrusão mais espêssa de Reichenfels, Wagner (8) cita a existência de inclusões gabróidas, nitidamente delimitadas da rocha principal diabásica.

Os fenômenos múltiplos de contacto, nas proximidades imediatas de tôdas as camadas diabásicas, bem descritas por Wagner (8), são considerados por êle como sendo uma prova de diferenciação magmática «in loco».

- Os fenômenos do contacto são bem pronunciados em rochas permianas, intrudidas pelo diabásio em Laranjal.

Tratando-se de várias fases eruptivas, é natural que, durante alguma fase, uma parte do magma diabásico pudesse ficar bastante tempo entre os sedimentos, para metamorfizar as rochas sedimentares.

De um foco eruptivo podem provir as variedades mais importantes das rochas basálticas do Brasil e das regiões próximas.

Em Laranjal estão representados diabásios e porfiritos, com suas estruturas típicas e de composição mineralógica normal.

Esta divisão em porfiritos e diabásios normais já foi proposta por Hussak (5), à base do estudo microscópico das rochas basálticas do vale do Paranapanema.

Como veremos mais adiante, em todo o sul do Brasil os porfiritos e os diabásios se acham juntos, e esta distribuição se explica pela gênese comum do mesmo foco eruptivo, com a separação produzida pelas várias fases eruptivas.

Entre os vários fragmentos arrastados pelos diabásios de Laranjal acham-se também fragmentos do gabro, trazidos de grandes profundidades.

O gabro, como um produto de diferenciação em grande profundidade, não podia aparecer como um produto de diferenciação dos diabásios, que se formam na superfície da terra ou de pouca profundidade relativamente aos gabros. 
Os meláfiros tāmbém faltam em Laranjal, mas os poros são abundantes em frações centrais dos diabásios.

Sem dúvida, durante as erupções prolongadas de Laranjal ocorreram amplas efusões com estrutura porosa das lavas, mas estas rochas não deixaram vestígios, porque foram completamente eliminadas pela erosão.

Esta porosidade dos diabásios de Laranjal diminue consideràvelmente a resistência da rocha à intempérie e à destruição mecânica.

Temos aquí um exemplo de importância da análise microscópica das rochas eruptivas para a aplicação das mesmas nas construções e nas estradas.

\section{Lâmina n. ${ }^{\circ} 65$.}

Pedreira do Chapadão, a $4 \mathrm{Km}$ a oeste de Campinas.

Diabásio principal colhido a $0,05 \mathrm{~m}$ da distância do veio macrocristalino intrusivo diabásico de espessura de 0,25 m.

Os diabásios de Campinas pertencem às intrusões basálticas em formação glacial permiana.

Estrutura ofítica. A composição de plagioclásios varia entre $\mathrm{An}_{44}$ - $\mathrm{An}_{66}$. Como nos diabásios normais de Laranjal observa-se a extinção deslizante contínua dos plagioclásios, que demonstra pela mudança do ângulo entre eixos óticos a acidez maior das bordas dos mesmos. Albita.

As hemitropias observadas são Karlsbad, Albito-Karlsbad e

$O$ piroxênio tem as constantes seguintes:

$$
\begin{aligned}
& \mathrm{Ng}-\mathrm{Np}=0,023 \\
& \mathrm{Nm}=\mathrm{Np}=0,0033 \\
& 2 \mathrm{~V}=30^{\circ} ; \mathrm{c} \wedge \mathrm{Z}=37^{\circ} 30^{\prime} . \\
& \mathrm{Nm}=1,7188
\end{aligned}
$$

A magnetita ilmenítica demonstra contornos irregulares, mas, em geral, sem ramificações arboriformes caraterísticas para os diabásios de esfriamento brusco.

Os minerais acessórios são:

A serpentina verde, de estrutura fibrosa, formando pseudomorfoses segundo olivina.

O quarzo, em grãos informes, que se amoldam a outros componentes com muitas inclusões.

Biotita marrom em fragmentos informes, bastante raros. A apatita forma agulhas de espessura máxima de 0,01 $\mathrm{mm}$. 
A composição volumétrica da rocha foi definida pela platina de Shand:

\begin{tabular}{lr} 
Labrador & $53,1 \%$ \\
Augita & $36,7 \%$ \\
Magnetita & $8,0 \%$ \\
Olivina + viridita & $1,7 \%$ \\
Apatita & $0,37 \%$ \\
Biotita & $0,08 \%$ \\
Quarzo & $0,05 \%$ \\
\hline & $100 \%$
\end{tabular}

Trata-se aquí da rocha diabásica ofítica, que aparece no dique de Laranjal como zona intermediária entre o contacto e a parte central do dique.

Em Campinas, o limite entre a zona predevoniana e a zona permiana glacial está determinada pelas falhas.

A oeste de Campinas os estratos permianos têm uma orientação horizontal.

Evidentemente, o afundamento paulatino dás formações para oeste é resultado de um sistema de falhas, que tem a orientação paralela em geral aos limites das formações.

Outro sistema de falhas cruza normalmente o primeiro e é mais difícil de observar, porque não aparece em forma dos limites entre as formações, mas sòmente, às vêzes, em forma das erupções diabásicas.

As erupç̃̃es diabásicas também se efetuaram pelo primeiro sistema de falhas, e assim é fàcil compreender a semelhança dos diabásios de Campinas e de Laranjal.

A comparação dos diabásios fornece um método excelente de orientar-se em um sistema tectônico complexo.

Já no ano de 1885, Derby (9) (pág. 320) observou o rumo predominante das erupções diabásicas, que concordam com os limites das formações.

\section{Lâmina n. ${ }^{\circ} 66$.}

Amostra colhida da mesma pedreira, porém de um nível de 10 metros acima da amostra da lâmina n. 65.

A estrutura e os componentes ficam os mesmos, mas os plagioclásios têm, muitas vêzes, o manto do ortósio sódico e na mesostasis aparece o micropegmatito. 


\section{Lâmina n. 58.}

Veio diabásico de grãos mais grossos do que o diabásio prin. cipal, analisado nas lâminas n. ${ }^{\circ} 65$ e 66 . A espessura do veio é de $0,25 \mathrm{~m}$. A estrutura é intermediária entre ofítica e porfirítica. Os piroxênios aparecem em parte em formas bem definidas.

$O$ idiomorfismo dos piroxênios manifesta-se aliás em clivagens (110) e (1 10$)$ bem distintas.

Nos diabásios normais estas clivagens se manifestam em linhas tortuosas e não paralelas como deveriam ser.

Imprensados entre os plagioclásios os piroxênios não podem desenvolver suas faces cristalinas e sua estrutura molecular com completa regularidade.

Os plagioclásios têm muitas vêzes os contactos curvilíneos com os piroxênios.

A mesostasis é abundante.

A magnetita ilmenítica, às vêzes em esqueletos, quase sempre é ligada aos piroxênios.

O quarzo ocorre em aglomerações de grãos informes e em micropegmatitos.

A composição dos plagioclásios varia entre $\mathrm{An}_{46}-\mathrm{An}_{60}$ no centro, descendo até $A_{27}$ nas bordas.

As hemitropias são Albita-Karlsbad, Albita e correspondente a Manebach.

O piroxênio forma as hemitropias caraterísticas segundo (100) com coincidência de $\mathrm{Np}^{\prime}$ de um com $\mathrm{Ng}^{\prime}$ de outro e de $\mathrm{Np}^{\prime \prime}$ dêste com $\mathrm{Ng}^{\prime}$ do primeiro e com a coincidência de $\mathrm{Nm}^{\prime \prime}=\mathrm{Nm}$ '.

Trata-se de uma variação muito semelhante ao porfirito da parte central (vide lâmina n. ${ }^{\circ}$ 165) do dique de Laranjal.

A diferença das formas exteriores assumidas por estas rochas é grande, porque no caso da lâmina 58, temos um dique de 0,25 $\mathrm{m}$ de espessura e no caso da lâmina n. ${ }^{\circ} 165$ uma intrusão maciça de dezenas de metros de espessura.

A diferença de nível explica em parte esta diferença.

A parte central do dique de Laranjal acha-se numa altitude de 500 metros e a pedreira de Chapadão numa altitude de 700 metros.

É provável que se encontrem a 200 metros abaixo da pedreira de Chapadão os diques mais fortes da mesma rocha.

Nas proximidades de Laranjal não se observam as camadas intrusivas diabásicas em tal abundância como na região de Campinas. 
Evidentemente, elas foram, em Laranjal, eliminadas pela erosão que eliminou também os sedimentos de $400-500$ metros de espessura, situados acima.

Nas altitudes desaparecidas de 1000 a 1100 metros, achavamse as rochas melafíricas que caraterizam as efusões ou as intrusões de pouca profundidade que não supera $100-200$ metros aproximadamente (vide os meláfiros de Pedregulhos e de Franca).

Estas relações entre as rochas basálticas e as altitudes observaram-se na faixa próxima à faixa cristalina dos gneiss e xistos.

Afastando-se desta faixa os meláfiros aparecem já nas altitudes de 510 a 530 metros nas proximidades de Jaú, numa altitude de 633 metros na Estação de Silveira do Vale, 610 metros na Estação Experimental de Ribeirão Preto, descendo até 485 metros nos bordos do rio Paranapanema em Pirajú, e até 150 - $180 \mathrm{~m}$ em Guaíra do Paraná.

As rochas diabásicas indicam com seus níveis que depois do período eruptivo os movimentos verticais da crosta terrestre continuaram segundo as falhas, que em conjunto formaram o vale atual do rio Paraná e do rio Paranapanema.

\section{Lâmina n. ${ }^{\circ} 170$.}

Grande pedreira a $5 \mathrm{Km}$ a sueste de Limeira. Altitude 500 metros. Estrutura porfirítica com mesostasis abundante. nítidas.

Plagioclásios e piroxênios idiomorfos e com as clivagens

Magnetita ilmenítica, em forma dos grãos corroidos, ligada com cristais de piroxênio.

Em relação com outros diabásios e augito-porfiritos, observa-se a abundância de apatita na mesostasis.

A composição dos plagioclásios oscila entre $A n_{74}-A n_{56}$, com hemitropias segundo Karlsbad e Albita-Karlsbad.

$O$ piroxênio tem o pleocroísmo muito fraco. $2 \mathrm{~V}=44^{\circ} ; \mathrm{Z} \wedge \mathrm{c}=$ $45^{\circ}$ (determinados pela platina Fedorow). $\mathrm{Ng}-\mathrm{Np}=0,0259$, $\mathrm{Ng}-\mathrm{Nm}=0,0241$.

A dispersão de eixos b́ticos é muito fraca para o eixo b́tico próximo de $\mathrm{c}$ e invisível para o outro eixo ótico, resultando $p>v$ para o primeiro.

Observam-se as hemitropias numerosas com o eixo de hemi-

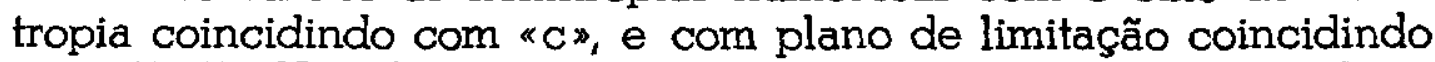
com (100). $\mathrm{Ng}^{\prime}$ de uma metade $=\mathrm{Np}^{\prime \prime}$ de outra, e $\mathrm{Ng}^{\prime \prime}$ desta $=\mathrm{Np}$ ' da primeira. $\mathrm{Nm}^{\prime}=\mathrm{Nm}^{\prime \prime}$. Estas hemitropias são encontradas em todos os diabásios e porfiritos diabásicos do Estado de São Paulo, e são uma prova importantẹ da origem do magma comum. 
O piroxênio aproxima-se mais de todos para o pijonita do lago Onega, descrito por Wahl (10).

A dispersão fraca indica a ausência de ferro e o ângulo $45^{\circ}$ entre $\mathrm{c}$ e $\mathrm{Z}$, indica o conteúdo máximo de $\mathrm{Ca}$.

Pela composição dos feldspatos e dos piroxênios a rocha de Limeira (vide lâmina 16l) parece-se muito com a parte central do dique de Laranjal.

A semelhança vai mais longe: ambos os diques encontram-se no limite entre a base permiana glacial e a formação de Tatú, imediatamente superior pela situação estratigráfica.

A coincidência explica-se pela situação quase horizontal das camadas permianas entre Laranjal e Limeira com a distância de $70 \mathrm{Km}$ em linha reta.

A base da pedreira de Laranjal tem a altitude de 550 metros e, a de Limeira, a altitude de 500 metros.

Os porfiritos diabásicos são as rochas de veios e diques e aparecem em altitudes com desníveis de centenas de metros (por exemplo: Campinas e Laranjal). Onde o desenvolvimento das rochas é igual em magnitude, o desnível fica menor.

\section{Lâmina n. 205.}

Brotas, estação da Estrada de Ferro Paulista. Rocha muito consistente, viva. O microscópio revela na lâmina muitas mudanças que transformaram a rocha em agregado de minerais primários e secundários.

Entre êsses se observam cloritas e zeolitas.

Não podemos, neste trabalho, entrar em detalhes de transformação dos diabásios, que merecem um estudo especial, em vista da importância dos minerais secundários para a formação do solo.

A transformação atacou principalmente a mesostasis abundante.

Os plagioclásios e os piroxênios conservaram-se na maior parte, demonstrando as mesmas propriedades óticas que a lâmina 170 (Limeira), com uma tendência dos plagioclásios para aumento da parte albítica.

Observam-se várias hemitropias segundo (001) com An 48 .

De conformidade com esta tendência aumentou a quantidade de mesostasis.

A altitude de 620 metros, 120 metros acima da pedreira de Limeira, indica o afastamento do nível dos focos maiores dos porfiritos diabásicos.

A apatita é abundante na mesostasis, como no porfirito diabásico de Limeira. 
Lâmina n. 162 (Fig. 5 e 6).

Corte da estrada Tietê - Laranjal, a 6,0 Km de Tietê.

Estrutura nitidamente porfirítica, com os plagioclásios e piroxênios idiomorfos.

Os piroxênios são estendidos paralelamente a (100) e menos crescidos normalmente a (100).

O eixo «a» dá o rumo de menor crescimento.

As hemitropias com o eixo de hemitropia "C», denominadas até agora hemitropias segundo (100), porque o plano (100) é o plano de junção, em cortes normais ao plano (100), demonstram a linha divisória muito nítida.

Em cortes inclinados com relação a (100), a linha divisora alarga-se até uma faixa, que mostra a interferência diferente de ambas as metades da hemitropia, porque a interferência da faixa divisora se compõe das interferências de duas cunhas, que são as prolongações das duas metades da hemitropia.

Inclinando mais fortemente a lâmina com relação ao plano do corte feito normalmente ao (100), aquela faixa de interferência multiplica-se.

Errôneamente, muitos petrógrafos falam neste caso de hemitropias polissintéticas, observadas em piroxênios, por analogia com as faixas múltiplas de plagioclásios.

Verdadeiras faixas polissintéticas são raras nos piroxênios.

As constantes do piroxênio são:

$\mathrm{c} \wedge \mathrm{Z}=45$, porque $\mathrm{Nm}$ de ambas as metades de hemitropias coincidem, e o eixo de maior refração de uma metade coincide com o eixo de menor refração do outro.

O eixo ótico próximo ao "C" forma com êste o ângulo de $22^{\circ}$ $-25^{\circ} .2 \mathrm{~V}=47^{\circ}$ - Temos então o pijonita.

Os plagioclásios oscilam entre $\mathrm{An}_{35}-\mathrm{An}_{45}$ nas partes centrais.

Nos plagioclásios menores observam-se as percentagens menores de An, porque os cortes menores correspondem às partes exteriores dos cristais grandes.

Muitas vêzes os plagioclásios têm os mantos formados pelo ortósio sódico, com $2 \mathrm{~V}=-68^{\circ}$.

\section{Lâmina n. ${ }^{\circ} 81$.}

A rocha diabásica forma a margem da cachoeira do rio Piracicaba na cidade do mesmo nome.

Os plagioclásios são idiomorfos. O idiomorfismo dos piroxênios é menos nítido, mas a alongação dos mesmos paralela a (010) é bem observada em abundantes hemitropias com o eixo de hemitropia paralela a «c». 
Os eixos de refração médià coincidem, e o eixo de maior refração coincide com 0 de menor refração da outra metade da hemitropia.

Consegùentemente, $\mathrm{Z} \wedge \mathrm{c}=45^{\circ} .2 \mathrm{~V}=48^{\circ}$.

A composição de plagioclásios nas partes centrais em têrmo médio é $\mathrm{An}_{46}$.

A altitude da borda da cachoeira é de 490 metros, aproximadamente.

\section{Lâmina n. ${ }^{\circ} 157$ (Fig. 1 e 2).}

Diabásio da orla direita do rio Jaguarí, 100 metros águas abaixo da cachoeira "Funil», nas proximidades de Cosmópolis.

Esta rocha possue a estrutura intermediária entre a porfirítica e a ofítica, com os plagioclásios idiomorfos e os piroxênios que em parte se amoldam aos plagioclásios e em parte mostram as suas próprias formas.

A composição de feldspatos, nas partes centrais, oscila entre $\mathrm{An}_{46}$ e $\mathrm{An}_{56}$.

As 3 hemitropias observadas são as de Karlsbad.

A mesostasis é notável pelo seu desenvolvimento volumétrico. $\mathrm{Z} \wedge \mathrm{c}=45^{\circ} .2 \mathrm{~V}=42^{\circ}-52^{\circ}$.

$\mathrm{Ng}-\mathrm{Np}=0,0298$. As hemitropias com o eixo de refração média comum são raras. $\AA$ altitude é de 520 metros.

\section{Lâmina n. ${ }^{\circ} 28$.}

$11 \mathrm{Km}$ ao sul de Casa Branca, no Estado de São Paulo.

Pêso específico 2,975. Granulação média. Estrutura ofitica - porfirítica. Os feldspatos não se juntam em uma rede ziguezagueada, como em uma estrutura tìpicamente ofítica.

Certos plagioclásios são ligados entre si, e alguns ficam isolados pelos outros componentes da rocha.

Esta estrutura corresponde à composição média de plagioclásios de $\mathrm{An}_{\mathrm{B} 0}$.

A magnetita forma em parte os esqueletos caraterísticos idiomorfos, e em parte ocupa os interstícios entre os plagioclásios e os piroxênios.

A magnetita é em parte também transformada em pirita.

A mesostasis, com abundantes agulhas de apatita, ocupa, aproximadamente, $15 \%$ do volume total da rocha, e está fortemente cloritizada.

$O$ piroxênio forma as hemitropias com o eixo de hemitropia $\mathrm{Nm}$ comum e $\mathrm{Ng}$ de $\mathrm{um}=\mathrm{Np}$ de outro. 
Conseqùentemente, $\mathrm{Z} \wedge(001)=45^{\circ} .2 \mathrm{~V}$ oscila entre 30 $-40^{\circ}$.

Entre os minerais acessórios notamos também o quarzo com revestimento de opala.

O local da ocorrência acha-se na faixa glacial permiana e na altitude de 600 metros aproximadamente, correspondendo aos diabásios na proximidade de Campinas.

\section{Lâmina n.ำ 33.}

Orla direita do rio Pardo, $20 \mathrm{Km}$ aproximadamente a este de Barretos.

O diabásio tem a granulação fina e a estrutura ofítica, com os plagioclasios idiomorfos.

A composição dos diabásios oscila entre $\AA n_{63}-\AA_{67}$ com as hemitropias de Periclínio e de Karlsbad.

Como já observamos em outros diabásios de estrutura ofítica, os piroxênios não têm sua clivagem normal (110) desenvolvida nitidamente.

A determinação dos ângulos caraterísticos não pode ser exata por falta da base firme. Aproximadamente $2 \mathrm{~V}=49^{\circ}$ e $\mathrm{c} \wedge \mathrm{Z}=$ 38. $\mathrm{Ng}-\mathrm{Np}=0,023 ; \mathrm{Nm}-\mathrm{Np}=0,004$.

A mesostasis é escassa e quase completamente cloritizada.

Como acontece em geral em rochas de estrutura ofítica, a magnetita ilmenítica é distribuida pela massa total da rocha igualmente, sem relação alguma com os outros componentes.

Ao contrário, nos porfiritos diabásicos, os minérios tendem para aglomerações com o piroxênio.

O diabásio aflora na zona do arenito triássico de São Bento, na altitude de 580 metros, aproximadamente.

\section{Lâmina n. 42.}

A $18 \mathrm{Km}$ ao norte de Campinas, intrusão diabásica. Estrutura ofítica. A composição dos feldspatos oscila entre $65-68 \%$ no centro dos fenocristais, e entre 55 - $59 \%$ nas bordas dos mesmos.

Numa só lâmina observam-se duas variações notáveis dos piroxênios.

Uma espécie forma hemitropias, que já descrevemos várias vêzes, com eixo de refração médio comum para ambas as metades da hemitropia e com $\mathrm{Ng}$ de $\mathrm{um}=\mathrm{Np}$ de outro, que determina $\mathrm{Z} \wedge \mathrm{C}=45^{\circ}$.

Ao lado desta variação se encontra um augito monoaaxil geminado, onde $\circ$ ângulo entre $\mathrm{Ng}^{\prime}$ e $\mathrm{Ng}^{\prime \prime}=78^{\circ}$, aproximada- 
mente. $2 \mathrm{~V}$ da primeira augita $=40^{\circ}-50^{\circ} . \mathrm{Ng}-\mathrm{Np}=0,024$ e $\mathrm{Nm}-\mathrm{Np}=0,003$. fraca.

A dispersão dos eixos óticos em ambas as variedades é muito

Trata-se, evidentemente, de variedades da pijonita.

A olivina é relativamente abundante, transformada na maior parte em serpentina verde.

\section{Lâmina 44.}

Amostra tomada da intrusão diabásica, a $75 \mathrm{Km}$ de Ribeirão Preto, na estrada para São Paulo, na altitude de 685 metros, aproximadamente.

As dimensões do afloramento não foram determinadas, mas, em vista da composição da rocha, é provável que se trate de um dique de pouca espessura.

A estrutura é porfirítica com abundante mesostasis e com plagioclásios e piroxênios idiomorfos.

A magnetita ilmenítica, às vêzes, está incluida nos outros componentes, às vêzes inclue êsses.

A composição dos plagioclásios, de acôrdo com a estrutura, varia ao redor de $\mathrm{An}_{53}=$ 64.

Observadas as hemitropias albíticas, Manebach e Karlsbad.

As hemitropias do piroxênio estão, em sua maior parte, com os limites irregulares entre as metades de hemitropia. $2 \mathrm{~V}=56^{\circ}$, $\mathrm{Z} \wedge \mathrm{c}=45^{\circ}, \mathrm{Ng}-\mathrm{Np}=0,025$.

Entre os minerais acessórios estão presentes a apatita, relativamente abundante, como na maior parte dos porfiritos diabásicos ; o feldspato potássico-sódico, com Nm $=1,525$ e $2 \mathrm{~V}=-65^{\circ}$, e quarzo em grãos irregulares, em mesostasis.

O feldspato potássico-sódico, ou ortósio-sódico, forma a zona exterior dos plagioclásios.

\section{Lâmina n. ${ }^{\circ} 48$.}

Amostra colhida da intrusão diabásica, que aflora na estrada de Pôrto Ferreira para Ribeirão Preto, a 11,5 Km da primeira localidade, e na altitude de 555 metros.

A estrutura é porfirítica, de acôrdo com a composição de plagioclásios de $\mathrm{An}_{48}$ no centro do $\mathrm{An}_{38}$ nas bordas.

Os plagioclásios têm, como a maioria dos plagioclásios dos porfiritos diabásicos, os envoltórios de ortósio sódico, que, se bem que completamente ligado ao plagioclásio, é distinguido nìtidamente pela sua refração menor. $2 \mathrm{~V}$ dos ortósio-sódicos oscila entre $42^{\circ}$ e $-64^{\circ}$. 
É notável a presença de faialita com $2 \mathrm{~V}=50^{\circ}$ e $\mathrm{Nm}=1,79$, em grãos com contornos irregulares.

A mesostasis ocorre em forma de micropegmatita que passa gradualmente para os feldspatos potássico-sódicos das zonas exteriores dos plagioclásios.

A apatita em prismas alcança o diâmetro de $0,06 \mathrm{~mm}$.

As rochas de composição semelhante são muito abundantes na província de Latium da Itália e são classificadas por Johannsen como latitos. Mais adiante, voltaremos a êsse paralelismo notável entre os nossos diabásios e as rochas sódicas.

\section{Lâmina n. $^{\circ} 61$.}

Orla direita do Rio Piracicaba, $100 \mathrm{~m}$ aproximadamente águas abaixo da ponte da estrada Campinas - Limeira, e alguns metros a noroeste do contacto com o arenito permiano interglacial.

Um dique possante é cortado aquí pelo rio Piracicaba num nível de 500 metros, mais ou menos.

O rumo do dique é paralelo ao rumo da faixa permiana que é aquí norte-este-norte, aproximadamente.

A parte central do dique é um diabásio de grão grosso, passando gradualmente até um basalto preto afanítico perto do contacto.

A distância entre a parte central e o contacto é de 100 200 metros.

As dimensões e condições geológicas são iguais às do dique de Laranjal, e a composição mineralógica e caraterísticas petrográficas também quase idênticas.

A composição de plagioclásios em parte intermediária entre a parte central e a lateral do dique é de $60-64 \%$ An no centro dos fenocristais, e de $53-55^{\circ}$ An nas bordas. $2 \mathrm{~V}=+78^{\circ}$ no centro que corresponde a 59,5\% An segundo Berek.

As hemitropias utilizadas para medições eram as de AlbitaKarlsbad.

Os piroxênios têm $\mathrm{Ng}-\mathrm{Np}=0,024$.

É impossível determinar-se exatamente o ângulo entre $\mathrm{c}$ e Z por falta de clivagem nítida e paralela.

A estrutura do diabásio é intergranular.

\section{Lâmina n.ำ 67.}

A $7 \mathrm{Km}$ a leste de Itaí. Essse diabásio, um dos mais leves do Estado de São Paulo, pelo seu pêso específico 2,66, forma uma - saliência no planalto, com a altitude de $630 \mathrm{~m}$. 
O grão muito grosso indica uma estrutura porfirítica, que corresponde à composição mais ácida dos plagioclásios.

Nos centros dos plagioclásios a composição se encontra ao redor de $\mathrm{An}_{47}$.

Muitas vêzes a estrutura variável do plagioclásio, mas sem zonas nítidas no meio, passa bruscamente as duas zonas exteriores, bem delimitadas.

Neste caso, a zona intermediária é formada pela sanidina com $2 \mathrm{~V}=0$, e a zona exterior pelo anortósio com $2 \mathrm{~V}=-40^{\circ}$.

Os piroxênios têm os cristais idiomorfos, mas as linhas de clivagem são muitas vêzes um pouco curvadas, como nos proṭoclases, e não permitem uma determinação exata das constantes óticas.

Aproximadamente $\mathrm{Z} \wedge \mathrm{c}=38^{\circ}$ e $2 \mathrm{~V}=+34^{\circ}$.

A magnetita ilmenítica aglomera-se na maior parte nas bordas dos piroxênios.

\section{Lâmina n. ${ }^{\circ} 69$.}

Intrusão diabásica a $24 \mathrm{Km}$ a noroeste de Jacupiranga, na estrada para Xiririca.

Essa amostra apresenta um interêsse particular, devido à proximidade das rochas nefelínicas de Jacupiranga.

A estrutura da rocha é intermediária entre a ofítica e porfirítica, porque os plagioclásios são idiomorfos, mas os piroxênios na maior parte se amoldam aos plagioclásios e têm as clivagens com paralelismo um pouco deslocado.

Entretanto, em indivíduos hemítropos com o eixo de hemi. tropia "C» observa-se a largura reduzida normalmente a (100).

Como corresponde à estrutura intermediária entre duas mais importantes estruturas das rochas basálticas, ofítica e porfirítica, a composição dos plagioclásios nas partes centrais dos fenocristais oscila entre $\overline{A n}_{53}-\mathrm{An}_{56}$.

O piroxênio com um pleocró́smo fraco, difìcilmente observável nas lâminas de espessura de $0,02-0,003 \mathrm{~mm}$, tem $2 \mathrm{~V}$ que oscila entre $30^{\circ}-60^{\circ}$ e $\mathrm{Ng}-\mathrm{Np}=0,027$.

O mineral opaco mostra alguma secções octaédricas que são uma prova da magnetita, com grande probabilidade de mescla ilmenítica.

Os minerais acessórios são: viridita, horneblenda marrom e apatita.

\section{Lâmina n.• 78 .}

Manto de 50 metros de espessura, na altitude de 890 - 940 metros, a $20 \mathrm{Km}$ de Sacramento, na estrada para Araxá. 
A estrutura da rocha é ofítica, com os plagioclásios idiomorfos, mas encontram-se alguns raros plagioclásios muito maiores em tamanho do que os plagioclásios que formam a parte maior segundo - volume total ocupado pelos mesmos.

Os pequenos plagioclásios, mais numerosos, têm a composição $\mathrm{An}_{54}-{ }_{56}$, com $2 \mathrm{~V}=75^{\circ}$, que corresponde a $\mathrm{An}_{54}$ segundo Berek.

O plagioclásio grande, único na lâmina, tem a composição $A n_{45}$ no centro e $\AA n_{58}$ nas bordas, formando uma hemitropia segundo Karlsbad.

A parte central forma um elipsóide muito bem conservado.

Ao contrário, o manto exterior do elipsóide tem os contornos curvilíneos, com os piroxênios e magnetitas ilmeníticas entre as saliências. Evidentemente, durante a migração subterrânea do magma, os grandes cristais de plagioclásios ficaram introduzidos nos magmas de basicidade maior e em parte revolvidos.

No início da cristalização do magma básico, formaram-se os mantos mais básicos ao redor dos plagioclásios ácidos.

\section{Lâmina n.` 107.}

Amostra tomada $8 \mathrm{Km}$ a oeste de Ponte Grossa, Paraná.

Os diabásios têm a estrutura ofítica, de acôrdo com a composição dos plagioclásios : $\mathrm{An}_{60}-\mathrm{An}_{64}$ nas partes centrais e $\mathrm{An}_{39}$ - $\overline{A n}_{51}$ nas bordas. Hemitropias observadas: Albita-Karlsbad, Baveno direito, Karlsbad.

$\mathrm{O}$ piroxênio tem $\mathrm{Ng}-\mathrm{Np}=0,023$, determinado pela comparação com a birrefringência do plagioclásio.

\section{COMPARAÇÃO COM ÁFRICA DO SUL}

A maior parte das rochas basálticas estudadas pertence ao território do Estado de São Paulo, mas as nossas conclusões nestes estudos abrangerão uma área muito maior.

Calculando conservativamente, Guimarães (5) avalia a extensão das rochas basálticas em 680.000 quilômetros quadrados entre o Triângulo Mineiro e o Estado do Rio-Grande-do-Sul.

Baseando-se principalmente nas análises químicas, recalculadas para os valores de Niggli, Scorza (19) considera que as eruptivas básicas do Meio Norte, do Brasil Meridional e do Roroíma pertencem a magmas semelhantes.

Consideramos que o critério petrográfico fornece os dados suficientes para resolver esta questão interessante, e que as análises químicas, ainda que em forma dos gráficos de Niggli, muito em voga atualmente, determinam o parentesco dos magmas de forma sòmente aproximada. 
Um exemplo da incerteza que produz o estudo das análises químicas são os trabalhos, aliás excelentes e já várias vêzes citados, de Walther (11) sôbre os eruptivos básicos afro-brasileiro-argentinos.

No seu primeiro trabalho, Walther (3), na base de 25 análises químicas, coloca estas rochas entre as andesitas e basaltos.

Em seu trabalho mais recente Walther (11) admite o parentesco alcalínico de nossas rochas, como possível, dizendo, porém, que falta ainda a prova conclusiva dêste parentesco.

$O$ estudo das rochas, por intermédio do método Fedorow, fornece os detalhes que revelam os processos genéticos dos minerais-componentes, como já demonstramos por vêzes durante a descrição de várias amostras.

Para caraterizar uma rocha é sumamente importante observarem-se os detalhes do processo de formação dos minerais-componentes.

Com algumas exceções, observamos, como uma regra geral, a composição dos feldspatos de um centro básico com a passagem gradual para um envoltório ácido.

Podemos estabelecer as estreitas relações genéticas entre alguns gabros da faixa cristalina, os diabásios e os meláfiros do interior, exclusivamente na base do estudo petrográfico.

Ao contrário, as análises químicas destas rochas poderiam conduzir à admissão de dois diferentes magmas, que originam estas $r$ zhas, um andesítico e outro basáltico.

Diante disso, opinamos que as eruptivas básicas do Brasil Meridional, do Roroíma, do Meio Norte e de numerosíssimas ocorrências intermediárias, originaram-se do mesmo magma.

Pode-se mesmo fazer uma tentativa de estender nossas conclusões fora do Brasil.

Desde o aparecimento do livro de A. Wegener (20) no ano de 1915, discute-se muito sôbre a identidade das rochas básicas da América do Sul e da África do Sul.

Em sua obra, "The Geology of South Africa", Toit (21) escreve (pg. 14) : "Fortifica-se a evidência para sustentar a hipótese de Taylor e Wegener de que a América do Sul, África, Índia, Austrália e Antártica formaram as partes do grande continente Austral "Continente de Gondwana"....

Entretanto, a evidência petrográfica fornecida por Toit é insuficiente.

As páginas 330 - 331, do mesmo livro, tratam das estruturas e dos minerais dos doleritos, diabásios, taquilitos, gabros, noritos, trocolitos, picritos, dioritos e quarzo-doleritos sulafricanos.

Essa descrição, que toma duas páginas, poder-se-ia estender à maior parte das ocorrências das rochas basálticas-gabróides, africana, americana, européia, etc., mas as diferenças ficariam ocultas.]

Toit (21) cita também (pg. 513-517) algumas análises químicas novas das rochas básicas, mas já demonstramos que as análises químicas 
permitem distinguir entre as categorias principais das rochas eruptivas, mas fracassam ante a necessidade de caraterizar as variedades das rochas basálticas.

Uma descrição petrográfica melhor, das rochas básicas, se encontra na obra "Die Diamantenwueste Suedwest-Afrikas" de Kaiser (12) (pg. 213-216), onde K. Willmann trata de Karroo-doleritos do Namib do Sul.

$\mathrm{Na}$ descrição reconhecemos tôdas as variedades principais de nossas rochas, mas falta a composição porcentual dos feldspatos.

K. Willmann (12) cita entre os plagioclásios, o labrador, bitownita, labrador-bitownita, andesina e oligoclásio e menciona a presença de ortósio.

Como não há citação alguma de caraterísticas óticas dos ortósios é impossível dizer se se trata dos ortósios sódicos, por encontrada.

Igualmente, a descrição dos piroxênios é muito fragmentária.

Encontramos o fraco pleocroísmo dos nossos piroxênios também nos piroxênios de Namib, porém isto é tudo.

Nenhum dado numérico e nenhuma nota sôbre a dispersão caraterística dos piroxênios, que permita fàcilmente distinguir algumas variedades dêste mineral, sem efetuar as medições óticas, foi encontrada.

$O$ método de Fedorow foi utilizado por Leinz em seu trabalho «Ein Beitrag zur Kenntnis der Gesteine von Angola" (13).

Leinz (13) não menciona o método de determinação dos feldspatos por êle utilizado, porém determinações de feldspatos com a exatidão de um porcento da composição mineralógica não são possíveis com outros métodos mais antigos.

Ainda que em muitos casos tenham sido as composições dos feldspatos determinadas só aproximadamente, é possível traçar os paralelos entre as eruptivas básicas sulamericanas e de Angola, com maior nitidez, que em base das pesquisas sulafricanas, mencionadas anteriormente.

Existem em Angola, de acôrdo com Leinz (13) :

1. Basalto sem olivina de estrutura ofítica, com plagioclásio $A_{65}$, piroxênio $\mathrm{c}: \mathrm{Z}=50^{\circ}$ e magnetita abundante. Idade: preKarroo.

2. Basalto olivínico com plagioclásios $A_{n_{55}}$ e magnetita, de estrutura porfírica, raramente ofítica. Idade presumidamente: Karroo.

3. Diabase quarzífera com $A_{55}$, augito com c: $Z=48^{\circ}$, bronzito, quarzo e minério.

Leinz (13), de acôrdo com Monta e O'Donnell (14), considera o basalto sem olivina mais antigo do que o basalto olivínico em vista da decomposição principiante dos feldspatos $e$ uralitização dos augitos do primeiro.

Eis o que escreve Leinz (13): "É típico para os basaltos olivínicos a boa conservação dos componentes e a falta das deformações mecânicas ». 
Consideramos, pelas analogias com as nossas rochas, que os basaltos de Angola pertencem a um só período geológico, com diferenças de idade que não superam os intervalos entre as fases de um período eruptivo.

Em muitos pontos do Estado de São Paulo observamos os diabásios com os feldspatos decompostos, e as deformações mecânicas na mesma ocorrência com os diabásios perfeitamente conservados.

Notamos várias ocorrências em que as augitas ficaram deformadas pelas fôrças mecânicas de cristalização, sem, entretanto, afetar a rocha no seu todo.

A perfeita conservação dos feldspatos existe em rochas arqueanas e não pode ser utilizada como a prova da idade das rochas.

Com referência à olivina, notamos em várias ocorrências do Estado de São Paulo, originadas pelo mesmo magma, as eruptivas básicas com olivina e sem olivina.

É caraterístico em geral, que a olivina, caso se encontre presente, não ocupa tanto volume como os plagioclásios ou as augitas.

Leinz (13) não menciona a percentagem de olivina nos basaltos olivínicos de Angola.

Presumimos que a olivina não é predominante, nem tampouco pode equivaler aos plagioclásios pela parte volumétrica que ocupa no volume total da rocha.

Pela falta dos dados de refração, birrefringência, dispersão e localização dos eixos óticos não se pode dizer qual variedade de augitos predomina nos eruptivos básicos de Angola.

Tomamos a liberdade de supor que se trate da pijonita, com o ângulo de eixos óticos que oscila entre $0-50^{\circ}$, refração média de $1,680-$ 1,715 , birrefringência de $\mathrm{Ng}-\mathrm{Np}=0,023-0,027$ e o ângulo do eixo ótico de maior dispersão, com $\mathrm{c}=18^{\circ}-25^{\circ}$.

É um fato importante, que os basaltos, quarzo-diabásios, gabro e anortositos se encontram na região cristalina dos gneisses, granitos, xistos micáceos e filitos de Angola.

Aquí temos um paralelismo notável com as ocorrências na zona cristalina da América do Sul.

Em direção oeste os representantes de nossas eruptivas básicas estendem-se até a zona preandina.

Os estudos de G. Bodenbender (15) comprovaram que os eruptivos básicos de la Sierra de los Condores, até há pouco considerados como terciários, na realidade pertencem à idade triássica.

A determinação petrográfica destas rochas foi efetuada por $\mathrm{Ph}$. Kuenen, com o método de Fedorow :

Dolerita traquítica. Os plagioclásios geminados segundo Albita-Esterel, Albita, Karlsbad-Ä; têm as composições $\AA_{n} n_{28}-$ $\mathrm{An}_{35}$, mas $\mathrm{Ph}$. Kuenen admite a inexatidão dêstes limites em vista da zonalidade dos plagioclásios. $O$ diopsídio-augita tem $\circ$ ângulo de extinção máximo de $45^{\circ}$. A-de-mais, notou-se a presença de 
aegirino-augita, anfibólio basáltico, apatita e minerais secundários, calcita, calcedônio e analcima.

2. Basalto olivínico. Os fenocristais são sòmente de olivina, em parte serpentinizada nos bordos e nas grêtas. Em mesostasis: diopsídio-augita com a extinção de $45^{\circ}$, ortósio, vidro, biotita fortemente pleocróica, olivina, apatita e magnetita.

Se a comparação dos eruptivos básicos sulamericanos e sul-africanos é possível sòmente limitando-se a alguns poucos lugares melhor estudados, somos mais felizes fazendo a comparação geológica dêstes eruptivos, utilizando-nos da obra excelente, já mencionada, de Toit (21), sôbre a geologia sulafricana.

Esta comparação fornece a possibilidade de trazer luz sôbre o problema interessante da origem das nossas rochas básicas.

$\mathrm{Na}$ África do Sul os basaltos intrudem e cobrem o arenito de Cavernas, que é parte sedimentária superior do Sistema de Karroo.

O arenito de Cavernas é de origem eólica como o nosso arenito de São Bento, e igualmente da idade triássica.

$O$ arenito de Cavernas, como indica o nome, forma nos seus afloramentos numerosas cavernas e as formas bizarras de tôrres e morros com as paredes verticais.

Esta tendência observa-se também em arenito de São Bento, porém em muito menor grau, por causa do clima úmido do Brasil Meridional em comparação com o clima quase desértico da África do Sul.

A extensão extraordinária dos depósitos eólicos triássicos da América do Sul e da África do Sul, supera em superfície qualquer depósito aquático com exeção de depósitos marítimos.

Os depósitos marítimos são os maiores pela extensão e pela espessura, porém diferem muito dos depósitos eólicos pela lentidão de sua formação.

$\mathrm{Na} z o n a$ costeira dos mares podem formar-se ràpidamente as camadas espêssas de seixos e de areias grossas, mas estas camadas são limitadas à estreita faixa litoral de algumas dezenas de quilômetros de largura.

Â distância de $100-200 \mathrm{Km}$ da costa já se precisa um período geológico para a formação de alguns metros dos argilitos ou arenitos finos.

Em comparação com esta deposição lenta, os depósitos eólicos têm caráter muito diferente.

Durante a erupção do vulcão Descabezado, no ano de 1933, a cinza transportada pelo vento de oeste cobriu a zona precordilerana, na superfície de $20000 \mathrm{Km}$ quadrados, aproximadamente, por uma camada de $0,2 \mathrm{~m}$. de espessura média, que fornece em total, uma massa de... 4.000.000.000 toneladas de cinzas.

Os ventos de verão de oeste em Patagônia, que sopram durante meses com pequenos intervalos, com uma fôrça extraordinária numa faixa de centenas de quilômetros de largura, transportam uma massa de 
argilas, areia e pedras, muitas vêzes maior do que a quantidade indicada de cinza vulcânica.

Na Patagônia, a maior parte da massa transportada fica submersa no mar, sem possibilidade de retôrno ao continente no período geológico atual.

No início do período postglacial, quando ficaram submetidas à ação eólica as morenas da zona andina e subandina, o transporte devia ser ainda maior do que atualmente.

O continente ficou aliviado e a parte próxima do Oceano Atlântico recebeu quase tôdas as camadas sedimentares, levantadas pelos ventos.

Assim aumentou o desnível entre o mar e a terra.

Darwin (16) foi o primeiro que observou no litoral da Patagônia os fósseis marítimos de organismos pleistocênicos levantados até a altura de 100 metros.

Muito tempo depois, nos anos de 1901 - 1903, J. G. Andersson (17) calculou em 70 - 117 metros o afundamento das Ilhas Malvinas, no tempo postglacial.

Assim, o levantamento do continente correspondeu ao afundamento igual da zona marítima.

Não é possível avaliar o afundamento do continente sulamericano e sulafricano no período triássico com a exatidão usada para os movimentos iguais pleistocênicos calculados, por exemplo, em Fennoskandia em milímetros, mas com bastante certeza podemos afirmar que o afundamento alcançou algumas centenas de metros, baseando-se em quantidade de eruptivas brotadas pelo referido afundamento.

Segundo White (5), na Serra Geral, a espessura mínima dos derrames basálticos está acima de 610 metros, sem incluir a parte erodida.

Segundo Toit (21) a espessura máxima das lavas do sistema de Karroo é de 1500 metros, observado em Mont-aux-Sources, em Natal.

Essas cifras devem ser muito superiores à espessura da camada magmática do interior da terra, porque o magma durante a erupção se acumula ao redor das grêtas, mas as dimensões das massas eruptivas indicam a espessura de 400 - 500 metros da camada magmática antes da erupção.

Parece improvável que o arenito de São Bento de 265 metros de espessura máxima e de pêso específico de 2,2 - 2,3 pudesse desalojar uma camada magmática do pêso específico de $3-3,5$ e da espessura de 400-500 metros.

Entretanto, devemos tomar em consideração que o arenito eólico triássico era sòmente uma capa de uma série enorme de sedimentos, que se inicia com os tilitos de Gondwana.

Toit (21) calcula em 7100 metros a espessura do sistema de Gondwana na Africa do Sul, descontando as lavas basálticas superiores.

A espessura máxima observada dos depósitos do mesmo período geológico no Brasil Meridional é de 1700 metros. 
A espessura maior dos sedimentos da Africa do Sul corresponde proporcionalmente à maior espessura das lavas basálticas triássicas.

As erupções tinham tôdas as formas de um cataclismo de enormes extensões.

Entre os numerosos diques e usills» que ainda agora manifestam - tamanho extraordinário da catástrofe geológica não se encontra resto algum de vulcão.

Os vulcões são instrumentos demais insignificantes para efetuar um transporte da camada magmática de 1.000 .000 quilômetros quadrados e de 400 - 500 metros de espessura para a superfície.

É possível que as erupções se iniciaram por alguns pontos, mas as fendas eruptivas formaram-se ràpidamente para dissolver em correntes magmáticas os canais cilíndricos isolados de vulcões iniciais.

$\mathrm{Na}$ Africa do Sul, excepcionalmente, conservaram-se restos de vulcões, observados em número de 170 entre Steynsburg e Memel, mas, em geral, as erupções, por intermédio das fendas, tinham papel muito mais predominante.

O estudo detalhado das erupções basálticas sulamericanas e sulafricanas esclarece muitos problemas ainda obscuros sôbre as condições do magma no interior da terra.

A idéia da camada magmática líquida fica eliminada, porque uma acumulação sedimentária enorme durante o período de Gondwana acima do líquido, ainda com a intercalação das formações pregondwânicas, seria impossível, sem produzir as erupções vulcânicas.

O magma conservou, entretanto, bastante plasticidade, para penetrar na capa sedimentária e gradualmente abrir as fendas até a superfície da terra.

O estado intermediário, entre a consistência do cristal formado e - líquido, explica a presença dos fenocristais, que nasceram antes de começar as erupções.

Com a pressão diminuida decresceu a viscosidade do magma, ocasionando a reabsorção dos cristais já formados.

$O$ afundamento da parte americano-africana do continente Gondwana por 400-500 metros não ocasionou transgressão marítima alguma, porque a altitude absoluta do continente era, provàvelmente, muito superior ao ressalto do movimento vertical ocorrido.

Segundo de-Geer a ascensão da Escandinávia no tempo postglacial superou 300 metros e ainda continua.

Em vista da extensão enorme e da espessura total dos tilitos de Gondwana devemos admitir a maior espessura da coberta glacial gondwânica e o maior tamanho da ascenção potsglacial gondwânica, em comparação com a Fennoskandia.

Aliás, na realidade, não se tratava do afundamento total : aos $400-$ 500 metros de afundamento das camadas sedimentárias correspondeu a aparição, na superfície de terra e dentro das camadas próximas à 
superfície, das camadas basálticas, intrusivas e efusivas, de espessura de várias centenas de metros.

Concluindo, queremos ressaltar as conclusões seguintes:

1. As rochas básicas triássicas do Brasil dividem-se em três tipos distintos: meláfiros, diabásios e gabros.

Em geral, os meláfiros distinguem-se pela sua porosidade e maior acidez dos plagioclásios.

Como exceções existem os diabásios com labradoros e com poros abundantes (exemplo: camada superior diabásica das Sete Quedas).

A classificação em diabásios e augita-porfiritos na base de estrutura ofítica e porfirítica se refere sòmente às rochas estreitamente ligadas pela sua gênese, e deve ser usada apenas como uma subdivisão do tipo principal de diabásios.

Os três tipos principais produzem 3 tipos diferentes da terra-roxa:

a) Os meláfiros se desagregam mais ràpidamente pela sua porosidade e pela abundância de minerais componentes calcíferos secundários ;

b) Os diabásios fornecem as melhores variedades da «terra rcxa» pela sua composição mais básica e pela abundância dos microlitos de apatita ;

c) Os gabros são de maior resistência à decomposição atmosférica e fornecem ao solo quantidade maior de potássio e sódio do que outros tipos.

2. Aplicados separadamente, os tipos e subtipos das rochas basálticas podem ser utilizados como camadas-guias para a localização de falhas, que são o elemento principal da tectônica do Estado de São Paulo.

3. A análise petrográfica estabelece as relações genéticas estreitas entre os diabásios e os meláfiros do Brasil Meridional e alguns anortósiogabros da Serra da Mantiqueira e da Serra do Mar.

Êsses gabros são as rochas intermediárias entre os gabros normais e os essexitos.

D. Guimarães escreve (5): «E.P. de Oliveira admite a idade jurássica para as formações vulcânicas da Mata da Corda ; a ser exata esta presunção, as rochas alcalinas seriam contemporâneas do magma basáltico».

Os gabros intermediários são rochas de grande extensão e pela sua composição mineralógica e química distinguem-se nìtidamente dos gabros normais, ficando à mesma distância dos essexitos.

O nome "anortósio-gabro" ressaltaria o componente mineral mais caraterístico dêsses gabros. Nós os chamamos bocaiuvitos.

4. A composição mineralógica das rochas basálticas triássicas do Brasil demonstra que estas rochas provêm de uma camada básica magmática de extensão extraordinária, que atravessa os limites orientais do continente sulamericano. 
Por falta de estudos petrográficos não é ainda possível delimitar aproximadamente esta camada magmática nos outros continentes.

Na América do Sul êste magma formou as rochas basálticas triássicas do Brasil, Paraguai, e Uruguai, chegando até a zona preandrina nas proximidades de Córdoba.

5. As rochas basáltico-sódicas triássico-jurássicas do Brasil fornecem um exemplo mais grandioso da ligação estreita entre os movimentos epirogenéticos e as erupções das rochas atlânticas.

Quando Becke (12) descobriu, no ano de 1902, essa ligação, êle se baseou nas rochas eruptivas da Boêmia e limitou-se à época terciária.

G. T. Prior (12) realizou observações e conclusões quase idênticas às de Becke, e tinha à sua disposição sòmente as pesquisas petrográficogeológicas da África Oriental.

\section{AGRADECIMENTOS}

O autor deixa aquí consignados seus agradecimentos ao sr. J. E. de Paiva Neto pelas sugestões apresentadas e pela crítica do original.

\section{S U M M A R Y}

Physico-chemical and mineralogical studies of the soils of the São Paulo State by the Soil Division of The Agronomical Institute proved the existence of different violet soils in South-Brasil and its origin from basaltic rocks.

The Brasilian denomination "terra roxa" is already many times translated to "red soil", which is inexact, because the colour "roxa" corresponds to "violet" in English.

We must insist on the perfection of Brasilian expression, which gives the shortest and the best characteristic of the true violet soil, derived through the decomposition of basalts and diabases in the São Paulo State. The term "red soil" originated much confusion, because there are in this state many "red soils" of different origins, but the true violet soil is quite unique.

The violet colour of this soil appears very beautifully on the clean fields above the diabase hills at the distance of some hundreds of meters.

In the state of complete dryness the violet soil becomes coffee brown, but never gets a red colour.

The violet soil is the best soil of South America, on the contrary the red soils, which are mostly lateritic, are bad soils.

Some exceptions, do exist, of course.

The basalts produce laterites and other red soils of better qualities.

With the purpose to contribute to the study of the violet and the red soils the present essay was made, describing the basic rocks of South-Brasil, as mother rocks of soils.

The basic monograph of Djalma Guimarães "Magmatic Province of South-Brasil" (5), many times mentioned in the petrographic literature, definitively established the principal types and the mineral-components of triassic basic rocks in South-Brasil.

We have found scme varieties of basic rocks, not yet known, but considered important for the question of violet and red soils.

To soil science we consider of importance the discovery of acid melaphyres without labradors, which are essential for all other basaltic rocks, with exception of most basic and extreme types. 
These melaphyres have oligoclases and andesines, as its principal components, and are outcropping in many points of the Botucatú sandstone zone, from Franca up to Piraju in São Paulo State.

The melaphyres of Franca and Pedregulhos appear on a high "plateau" with the orientation NNW. wide.

In this direction the plateau is about $50 \mathrm{~km}$ long and in WSW direction about $25 \mathrm{~km}$

The slopes are very dissected, showing numerous big outcrops of melaphyrs, which rarely outcrop on the surface of the plateau, because the plateau is covered by variegated sands and sandstones.

Above all, in isolated patches, appear loose, conglomeratic beds, never above I $2 \mathrm{mt}$; with decomposed basaltic pebbles, and eolic sands.

These eolic sands are of much later age than the S. Bento sandstone below, which contains the melaphyres, because between the eolic sands above and the latest melaphyres the variegated sandstones and sands were deposited.

These sandstones have argillaceous cement and are very similar to Baurú sandstones in Rio Preto district.

Our melaphyres were not yet analyzed chemically, but the predominance of more acid plagioclases in relation to the diabases and the augite-porphyrites indicates more acid general composition.

We explain it by the separation of more basic part of the primitive basaltic magma in the depth, where the already formed augites and basic plagioclases remained.

Thus, the plutonitic phase of the magma, which originated the melaphyres, must have more basic plagioclases.

The search for these plutonites was directed to the cristalline zone of gneisses and schists, where the magmatic channels were discovered to the depth of several kilometers by the erosion.

In the Bocayuva district of the Paraná State several big outcrops of gabbroid rocks were found.

By microscopical examination we discovered the same absence of dinamometamorphic stresses which is the best characteristics of all triassic basaltic rocks in our region.

In some sections we found some bending of augites and plagioclases, which are common in many diabases and augite-porphyrites. Evidently these bendings happened during the eruption. In no case could these bendings be the result of dinamometamorphism.

The mineralogical composition of these gabbroid rocks is very singular.

They have the same augites which are found in diabases, augite-porphyrites and melaphyres.

The characteristic angle of these augites $\mathrm{c} \wedge \mathrm{Ng}$ is about $42^{\circ}-44^{\circ} 26^{\prime}$, as determined by D. Guimarães (5) in different samples gathered in the States of S. Paulo, Paraná, Sante Catarina and Rio Grande do Sul.

For the determination of this angle we used the Fedorow stage and we found that in all our rocks the augites form twins, with $\mathrm{Nm}$ common for both parts and $\mathrm{Ng}$ of one half coinciding with $\mathrm{Np}$ of other half.

In such a case $c \wedge \mathrm{Ng}=45^{\circ}$.

However there are many instances of big variations in optical properties of augites in the same sections.

The biggest variations happen with the angle $2 \mathrm{~V}$, which gives the angles $0^{\circ}-50^{\circ}$ in one section of the same rock.

But these variations happen in all basaltic rocks, from plutonites to extrusives.

The plagioclases, with $A n_{47}-A n_{60}$, give poikil itic texture, teing included in bigger crystals of anorthose, with $2 \mathrm{~V}=-54^{\circ}$.

The olivine in big rounded grains, only slightly altered, is always present.

As accessory minerals are big well formed prisms of apatite, ilmenitic magnetite and brown biotite. 
We diszวrзrad big outcrop3 of tha sam in the cristalline belt.

The only difference is in somewhat slighter basidity of plagioclases, which have $A n_{44}-A n_{59}$.

By mineralogical composition these rocks are between gabbros and essexites.

The next rocks would be shonkinites, which differ by the presence of orthoclase and nepheline, and small amount of plagioclase.

Thus we must introduce a new term, calling this rock bocaiuvite by the place where are the biggest and the most characteristic outcrops.

It seems difficult to put the bocaiuvites, with its sodic tendency, in the basaltic family of rocks, but there are no other plutonic phases in the crystalline belt, which would be nearer to our diabases.

We must have in view the anortosic rims of plagioclases in our augite-porphyrites, which have also sodic tendencies.

The essexites are common in. the South-Namib (12), appearing as the central parts of biggest dikes of monchiquites.

Unhappily the petrographic description of these essexites does not give the optical constants of its ortoclase, and we do not know if this ortoclase is sodic.

Very probably they are sodic by its genetic relations to monchiquites.

Little can be said about the part of basic rocks in the development of the orography and hidrography of crystalline zones, but in the rest of territory the basic rocks give to the surface its main characteristics.

It is well spen in the Saa Paulo State. There the basic rocks reached the surface by two systems of faults.

One system runs parallel to the limit of the crystalline belt, changing its direction from East-West in the South of the State to North-South in the North.

The biggest diabasic dikes belong to this system.

The other system has its faults directed normally to the first.

These faults show very clearly that the Paraná basin is the result of regional subsidence by step-faults.

The similar step-faults can be observed on Mato-Grosso side of the Paraná river and we have little doubt about the extension of this system to the basin of Paraguay river, more to the West.

The step-faults of bigger system, which run parallel to the limit of crystalline belt, have generally its downthrow on the side contrary to the crystalline formations.

There are some exceptions of this rule.

The Botucatú sandstone blocks are separated by faults, which have its downthrow on the side of older Passa Dois formation, but these faults have always little vertical displacements.

The biggest rivers, Paraná and Paranapanema, flow parallely to biggest faults but the affluents, as Tietê, cross these faults normally.

The eruptions occurred in extreme plains, through faults and fissures.

The elimination of lava was difficult and the channels of eruption were closed by hardened lava after the first outbreak.

The magma of following eruptions penetrated mostly in the São Bento sandstone, forming extensive sills.

Obviously the sills in lower strata must be rare, as the magma had much more resistance there, in view of the pression of overlaying formations.

Almost in all borings of S. Paulo State, which reached in some cases the considerable depth of $1600-1800 \mathrm{mts}$, the diabase was encountered in the whole extension of borings, but no sill of bigger dimensions was met below the S. Bento sandstone.

Mostly the diabase in biggest depths was in form of dikes. 
The diabasic intrusions and lavas strengthened the S. Bento sandstone, which resisted the following erosion much better as older formations.

Most of high plateaus in South-Brasil with abrupt sides are formed by S. Bento sand stone with diabasic or silicified layer.

Excepting the predevonian metamorphic belt all narrow valleys with abrupt sides are located in $\mathrm{S}$. Bento sandstone region.

By the different resistance against the erosion is easily explained the broad lower plains of 500 - $550 \mathrm{mt}$ altitude, on Passa Dois, Tubarão and Itararé formations, between high plateaus in the west and the crystalline coastal elevations in the East.

It is generally admitted that all differences of chemical and mineralogical composition of eruptive rocks come from chemical variations of the magma, which produced these rocks.

There are now established as many kinds of magma as magmatic rocks.

The differences of structure are mostly explained by modern thermal diagrams, based on enormous number of experiments.

To apply these diagrams for our rocks we must assume that in the nature the elements which form different combinations known as rocks are kept together during the whole forming process as they are kept in the furnace of the laboratory.

It would be the case of a quite isolated subterranean chamber, with no connections either with lower reservoirs or earth surface.

On the contrary, the basaltic eruptions were the product of an enormous network of aults and fissures, which the magma crossed during the process of crystallisation.

We mentioned already melaphyres, which were the product of the liquid part of the magma, after the separation of more basic crystals.

By the use of the Fedorow stage it was discovered that in most samples of diabase or augite-corphyrites the plagioclases of the same generation and dimensions have different chemical composition.

The differences in the case of plagioclases reach sometimes $10-20 \% A n$, which is much above the errors of the Fedorow method.

Evidently in diabases, augite-porphyrites and melaphyres we have mechanical mixures.

In other words many times the crystals were separated from the mother solution and mixed with a solution of other composition.

The Fedorow stage permits easily observe that most pyroxenes and plagioclases have rounded edges.

Generally such rounded edges are explained by magmatic reabsorption, and in some instances it is quite true.

The diabasic magma during the eruption was heavily charged with crystals and its liquid part was very near the solid state.

It is proved by no chemical action or very slight chemical action on the sides of transporting channels.

Only rarely the contact zone is several meters thick.

In every such case it is a contact of a big reservoir, where the magma remained till the solidification, or we have an instance of hydrothermal postvolcanic action.

In such a half-solid magma no chemical differentiation was possible.

In biggest sills and dikes of $S$. Paulo State we collected numerous samples at regular intervals normally to the sides of the intrusions.

In many cases we discovered evident changes in the structure of the rock, and in the mineralogical and chemical composition of the samples of the same intrusion, but the detailed geological investigation always showed that the changes come from different phases of the eruption, and are not the result of differentiation.

Different may be the case of bocaiuvites, which have consolidated as plutonitic masses far below the surface of the earth. 
The eruption began in the depth of many thousands of meters.

In this depth the magma was more liquid and gaseous and could absorb completely the fragments of crossed rocks.

The deepest strata, crossed by basaltic magma, were glass of acid composition, in half solid state, which readily was absorbed by moving basaltic magma, giving the more acid andesitic augite-porphyrites which in all diabasic dikes occupy the central parts, or cross the previously consolidated diabasic sills.

We admit the existence of many magmas of different chemical composition, but most of these secondary magmas were the products of mechanical mixing during the eruption of one magma, contaminated by one or two glasses in half liquid state; once consolidated as eruptive rocks the magmatic mixtures left no other traces.

The basaltic permotriassic eruptions by its extraordinary development supply the best evidence for the problem of the causes of volcanic action.

The accumulation of glacial-lacustrine and eolic deposits during the permo-triassic time reached a total thickness of thousands of meters and was the cause of a subsidence of corresponding dimensions.

There was one important factor which transformed this subsidence in a catastrophe of exceptional grandeur.

Generally the accumulation occurs in geo-sinclinals between parallel ridges, where the pressed magma reaches the surface through channels in the form of volcans, which are the safety valves of magmatic kettle.

There were no safety valves in the enormous Gondwana Continent, inaccessible for tectonic disturbances during the long permotriassic period, with exception of some little parts at its borders.

The loading of this continent occurred in very different manner, when compared to deltaic or sinclinal sedimentation, which generally have big changes of thickness on the belts of several kilometers broad.

The water-currents, maritime or continental, are steady.

On the contrary, the eolic deposits, which were the last load on the Gondwana Continent, covered it in large overlapping zones, with many changes of direction of wind during every year.

There were no mountains which could accumulate blown sands in belts.

Such belts by subsidence and consequent lateral movement of magma, as estipulated by isostatic theory, would gradually reestablish the balance of crustal forces.

The magma found the escape in vertical faults and fissures almost simultaneously over the shole continent.

We had not sinking and rising blocks of isostatic mutual displacement.

The sinking and rising movements happened in the whole continent.

The sinking part were the Gondwana sediments and the rising the basic magmas.

At first appeared melaphyric lavas, leaving behind heavier magma.

There was no lacking of volcanic gases, which opened the fissures for the oncoming lava.

When the eruptions of gas ceased and the expanding lavas closed the issues, as it was explained before, the subsidence of the continent continued some time more by the impulse taken.

In this last period of subsidence the lighter sediments sank deeper in he avier magma and the diabasic sills were intruded.

The difference of load on continental blocks explains the beginning of continental subsidence but cannot explain all phenomena correlated.

The vertical displacement of magma instead of lateral, explains naturally the positive gravity anomalies over deltas, which the isostatic theory cannot explain.

The oscillations of the level of the sea are well understood as the result of the sinking of lighter mass in heavier magma by inertia and later regaining of balance. 
Also many if not most part of volcanic outbreaks have its cause in the gravity pressure of [ the crust of the earth on the magma.

The magnetometric crossection of S. Paulo and Mato Grosso States (18) shows the gradual increase of the vertical component from the crystalline belts of both states toward the axis of Paraná basin.

The subsidence near this axis was the greatest and consequently the biggest are there basic intrusions.

The base of S. Bento sandstone comes there down to the $80 \mathrm{mts}$ level above the sea.

In the North of the S. Paulo State the total thickness of eruptive sills is about 125-150 $\mathrm{mts}$ and the base of the sandstone rises to the 700-750 $\mathrm{mts}$ level.

In the North-Uruguay the borings discovered a diabasic sill of $360 \mathrm{mts}$ thickness and here the base of the S. Bento sandstone goes down to $500 \mathrm{mts}$ below the sea-level.

The same gradual descending of the Gondwana System toward the South is observed in South Africa.

The Gondwana System has the maximum thickness of 27800 feet in the Cape Province: simultaneously with maximum total thickness of diabasic' sills and lavas of $4500 \mathrm{mts}$, and the lowest situation of Dwyka Tillite.

In Central Transvaal the Gondwana System is olny 2430 feet thick \according to A.du-Toit and the base of Dwyka Tillite rises the 1400 mts level.

Farther to the North in the Nyasaland border the Gondwana System is 18000 feet thick and we have there a group of lavas up to 4500 feet thick.

\section{LITERATURA CITADA}

1. Paiva Neto, J. E. de. A "fração argila" dos solos do Estado de São Paulo e seu estudo roentgenográfico. Bragantia 2:355-432. Fig. 1-4. Chapas 1-79. 1942.

2. Paiva Neto, J. E. de. "Perda ao rubro" em análises sumárias de terra. Bragantia 1:433-440. 1941 .

3. Walther, K. Contribución al conocimiento de las rocas "basálticas" de la formación de Gondwana em la América del Sud. Fig. 1-4. Lâminas 1-6. Montevideo. Imprensa Nacional. 1927.

4. Cunha, J. da, $\ominus$ João Bruno Lobo. As rochas nefelínicas como matéria prima para a fabricação do vidro de garrafa. Mineração e Metalurgia. 2:200-204. 1937.

5. Guimarães, Djalma. A província magmática do Brasil Merídional. Publ. Serviço Geológico do Estado de Minas Gerais. Belo Horizonte, pág. 1.64, 1933.

6. Johannsen, Albert. Em A descriptive petrography of the igneous rocks, vol. 3, pág. 1-360. Fig. 1-178. The University of Chicago Press, Chicago, Illinois, 1937.

7. Paiva, Glycon de. Condições dos jazjgos dos diabásios Myrmekiticos. Bol. Serviço Geológico e Mineralógico do Brasil 45:1-6. 1930.

8. Wagner, P. Differentiationsercheinungen in Diabasen des Ostthueringischen Hauptsattels. Mineralogische und Petrographische Mitteilungen. 50:107-180, fig. 1-27, diagr. 1-6, Leipzig, 1938.

9. Branner, John C. Em Geologia Elementar, 2." ed., pág. 1-396, fig. 1-174, Rio de Janeiro, 1915.

10. Winchell, Alexander N. Em Elements of Optical Mineralogy. 3.s ed., parte 2, pág. 1-459, fig. 1-361. New York, 1933.

11. Walther, K. Erupticos afro-brasileño-argentinos de edad permo-triasoeojurásica. La supuesta uniformidad del magma amelafídico y sus relaciones com la parentela alcalinítica. Sep. Bol. Instituto Geologico Montevideo (Uruguay) 24:117-167. Lâm. I-II. Fig.a. Montevideo, 1938.

12. Kaiser, E. Em Die Diamantenwueste Suedwest-Afrikas, vol. 1, pág. 1-321, fig. 1-58, Berlin, 1926. 
13. Leinz, V. Ein Beitrag zur Kenntnis der Gesteine von Angola. Zentralblatt filr Mineralogie und Geologie 1935:97-102. 1935.

14. Monta, V. e H. O. Donnell. Carte géologique de l'Angola. Lisboa, 1933.

15. Bodenbender, Guillemo. Triásico y terciario en la Falda Oriental. Bol. de la Academia Nacional de Ciencias (Cordoba) 31:73-139. 1929.

16. Derwin, Ch. R. Em Geological observations on coral reefs, volcanic islands and on South America, being the geology of the voyage of the Beagle. London, 1846.

17. Windhausen, Anselmo. Em Geologia Argentina, vol. 2, pág. 1-645, Lam. 1.58, fig. 1-214, Buenos Aires, 1931.

18. Gutmans, Marger e Paulo Vageler. Contribuição para o conhecimento das anomalias magnetométricas do Brasil Central. Bragantia 1:441-451, perf. I-II, 1941.

19. Scorza, E. P. Eruptivos básicos do Piauí. Mineração e Metalurgia 5:261-268. 1941.

20. Wegener, A. Em Die Entstehung der Kontinente und Ozeane, pág. 1-242, Brauns* chweig, 5. edição, 1936.

21. Toit, Alex I. Em The geology of South Africa, pág. 1-539, Oliver \& Boyd, 2." edição, 1939.

22. Machatschek, F. Em Das Relief der Erde, vol. 1, pág. I-545. 1938.

\section{EXPLICACÃO DAS ESTAMPAS}

Est. I - Fig. I - Magnetita titanífera arboriforme em diabásio do contacto com os tilitos permianis. Cachoeira Funil perto de Cosmbpolis, município de Campinas. Aumento: $100 \mathrm{X}$. (Ver descrição da lâm n. ${ }^{\circ}$ 157).

Fig. 2 - Magnetita titanífera arboriforme em diabásio do contacto com os tilitos permianos. Cachoeira Funil perto de Cosmópolis, município de Campinas. Aumento: $30 \mathrm{X}$.

Est. II - Fig. 3- Bocaiuvito de São Bento de Sapucal. Incluído em piroxênio um cristal de olivina com serpentinização incipiente. Aumento: $29 \mathrm{X}$. Nicoles cruzados. (Ver pág. 318)

Fig. 4 - Bocaiuvito do Município de Bocaiúva (Paraná). Um cristal grande de olivina com serpentinização incipiente pelas fendas. Aumento: 29 X. (Ver. pág. 318)

Est. III - Fig. 5 - Augita-porfírito do dique a $6 \mathrm{Km}$ da cidade de Tietê a leste-oeste. $O$ cristal idiomorfo do plagioclásio com envoltório do ortósio sódico. Aumento: $29 \mathrm{X}$. (Ver descrição da lâm. n.o 162).

Fig. 6- Augita-porfirito do dique a $6 \mathrm{Km}$ a leste-oeste da cidade de Tietê. Crescimento simultâneo do piroxênio e do plagioclásio. Aumento: $92,5 \mathrm{X}$. (Ver descrição da lầm. n. ${ }^{\circ}$ 162).

Est. IV - Fig. 7 - Bocaiuvito do município de Bocaiúva (Paraná). Nicoles cruzádos. Aumento: $29 \mathrm{X}$. Estrutura poiquilítica. Os plagioclásios no centro estão incluídos no cristal grande do ortósio ś́dico. Ao lado dêste cristal é visível o piroxênio geminado, com faixas paralelas produzidas pela interferência das extremidades-cunhas de ambas as metades da hemitropia, simulando a estrutura polissintética. (Ver pág. 320).

Fig. 8 - Manto basáltico superior de Franca. Aumento: 92,5 X. Estrutura intergranular. Plagioclásios com 53-61\% An. (Ver. pág. 320).

Est. V - Fig. 9 - Diabásio da fazenda do dr. Júlio Prestes, perto de Itapetininga. Estrutura intergranular. Aumento: $29 \mathrm{X}$. Plagioclásios com $60-$ $66 \%$ An. (Ver pág. 321).

Fig. IO - Augita-porfirito, fortemente decomposto, com plagioclásios e augistas idiomorfos. Taubaté $-85 \mathrm{Km}-$ Ubatuba. Dique em xistos metamorfos. (Ver pág. 321). 
Est. I

-

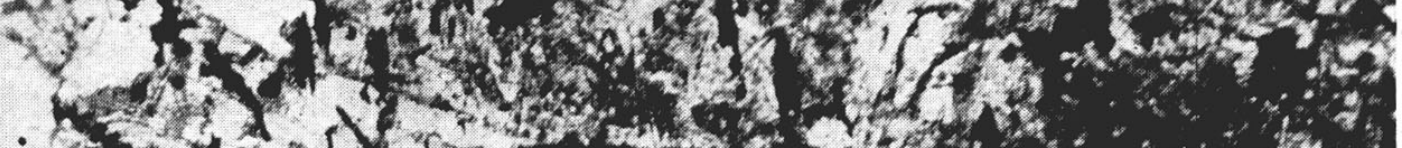

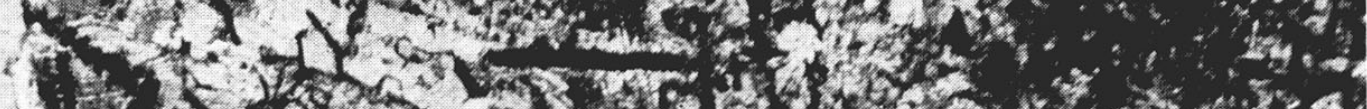

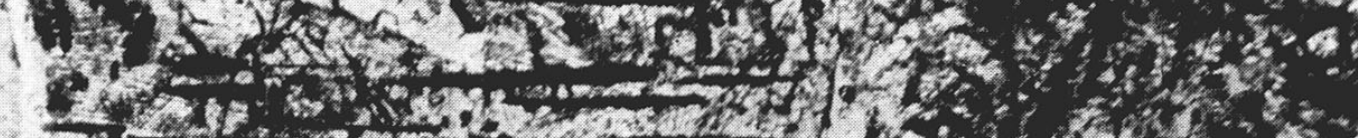

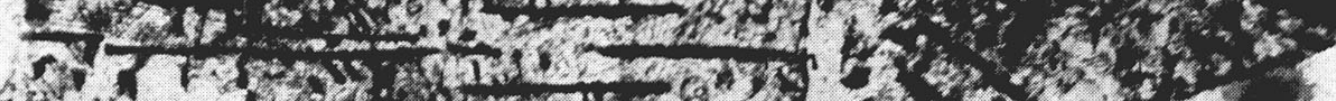
20.5

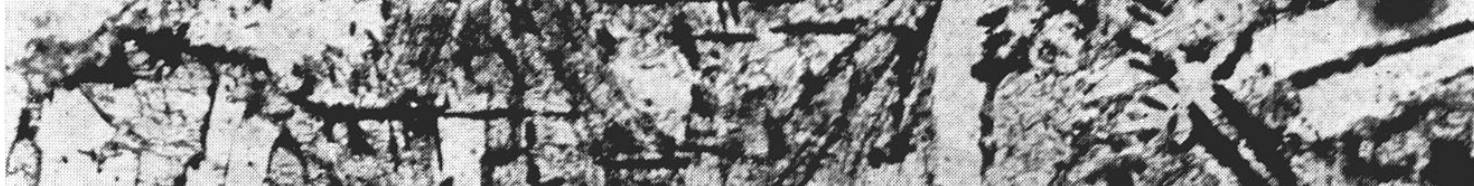

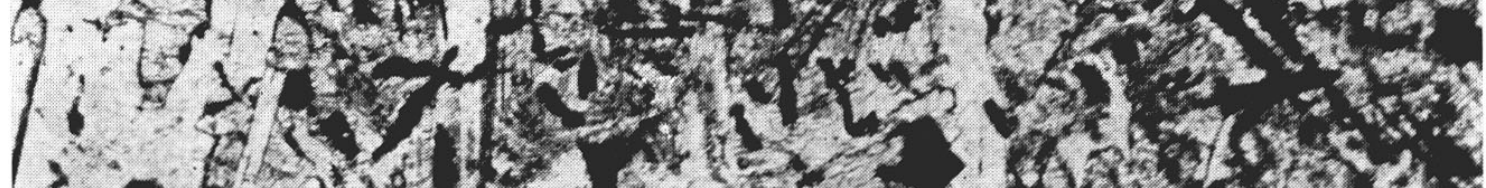
1
1

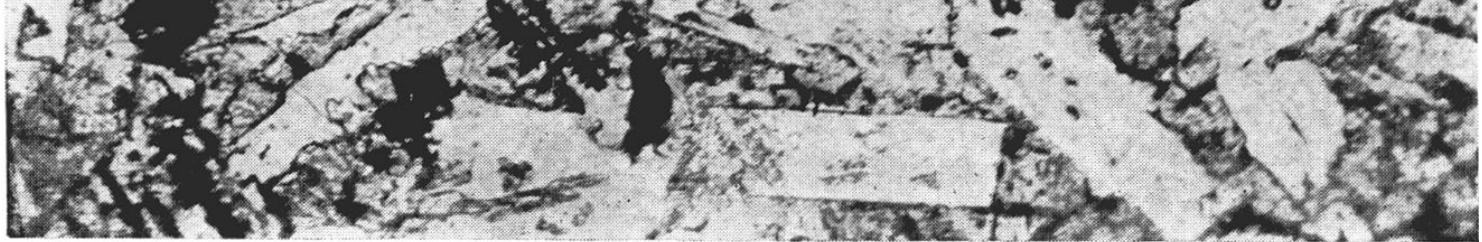


Est. II
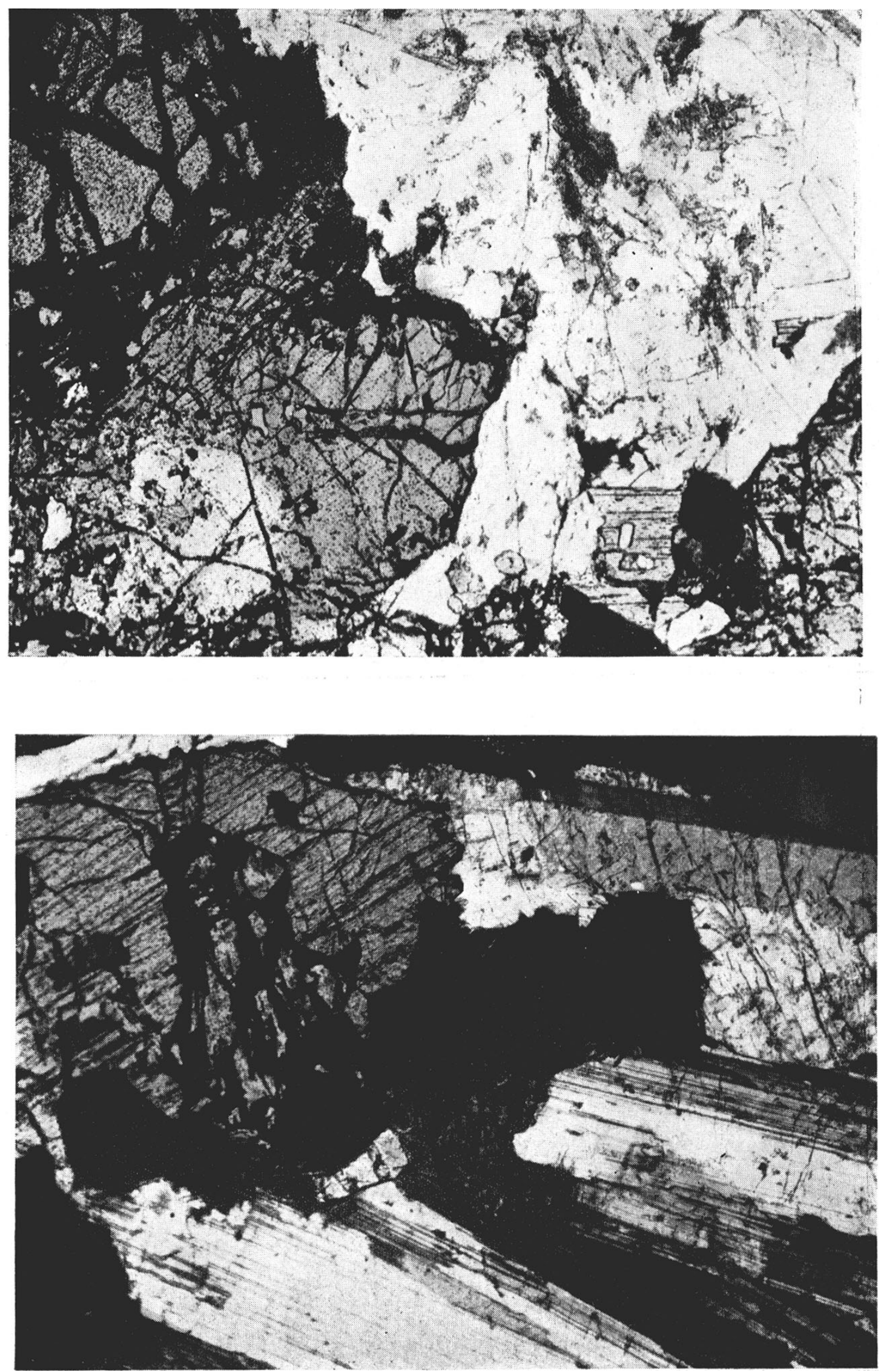
Est. III
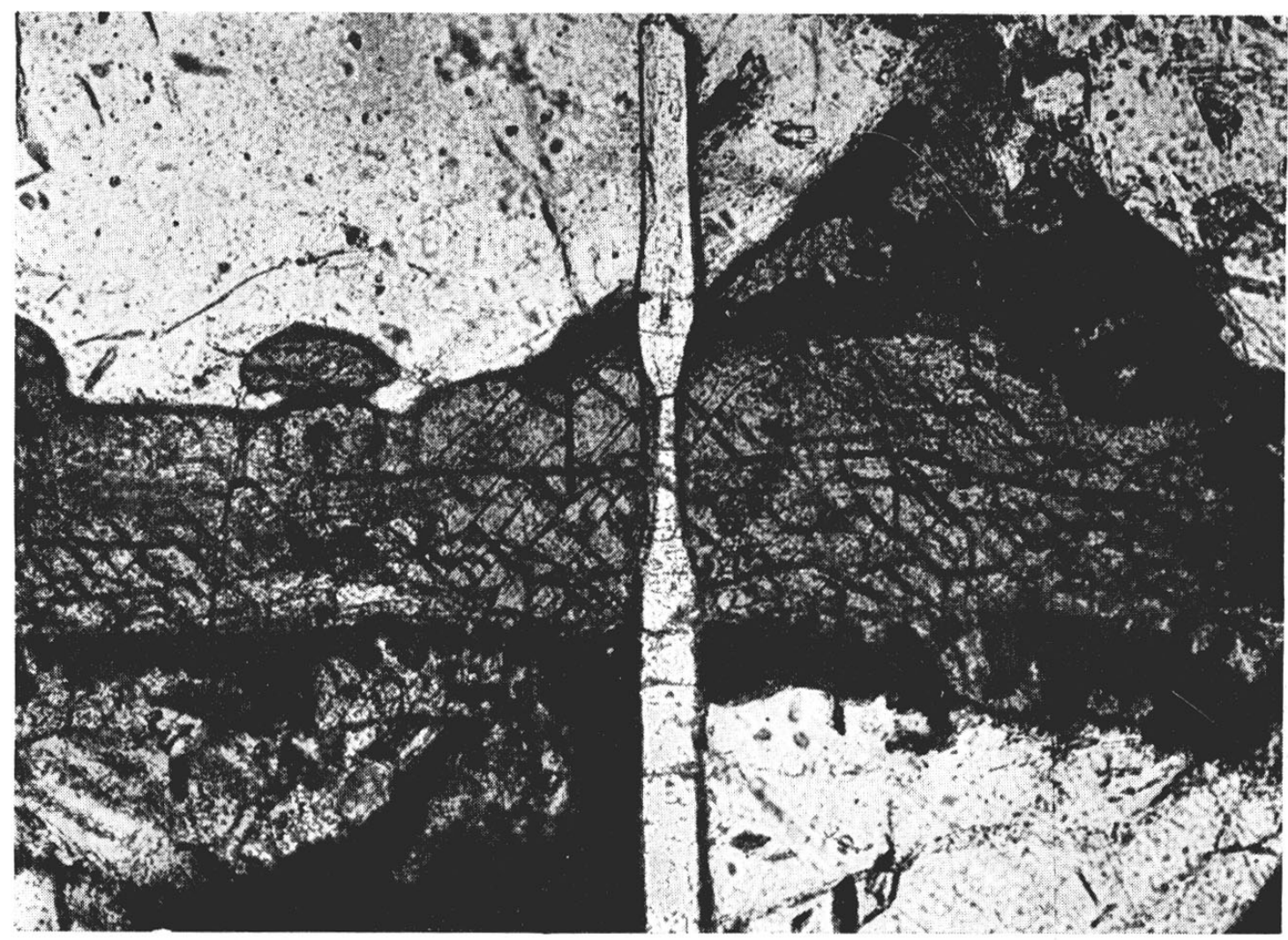

क्ष

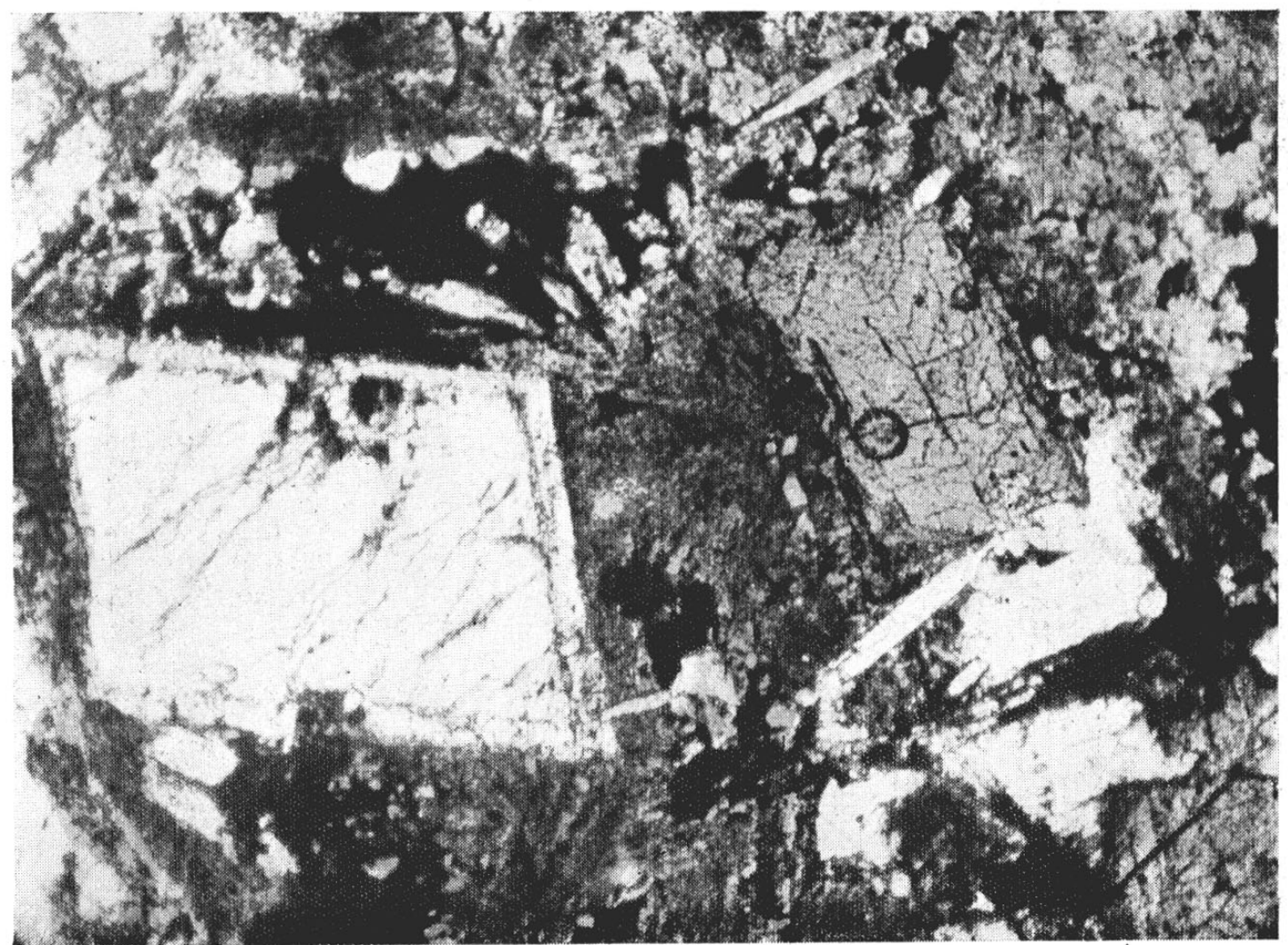


Est. IV
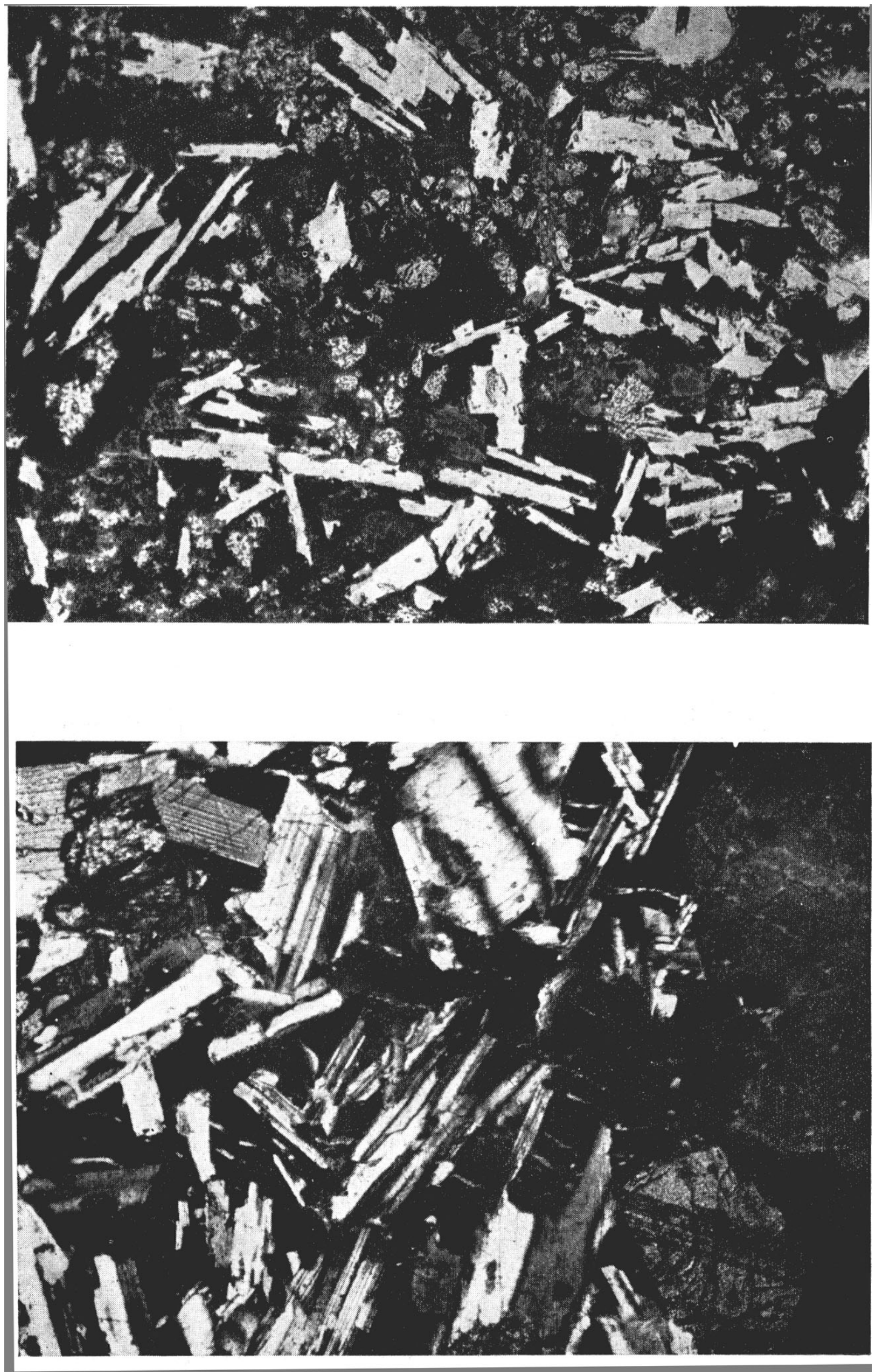

ت্ت 
Est. V
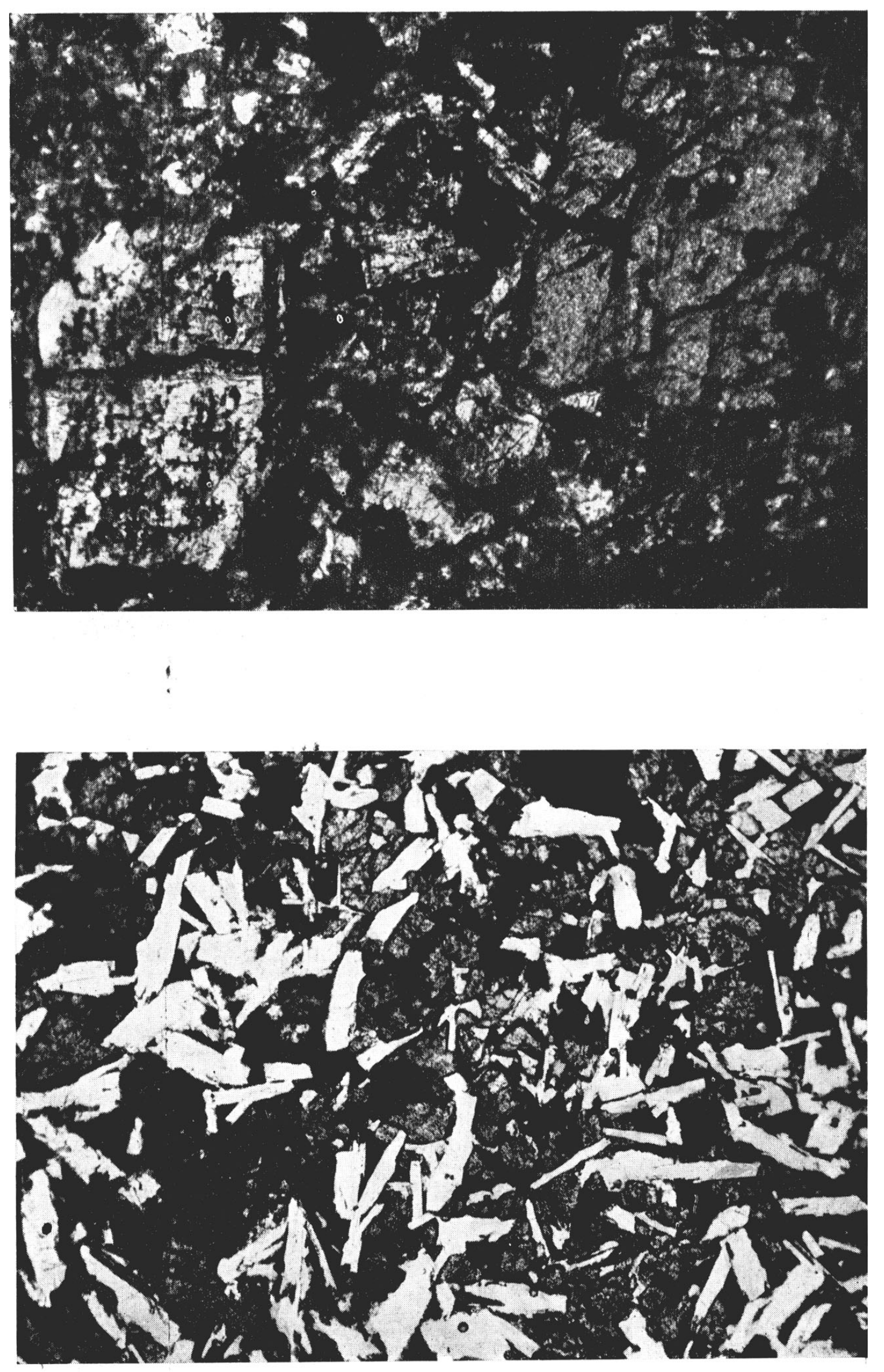